Article

\title{
Tuning of Luminescent and Magnetic Properties via Metal Doping of Zn-BTC Systems
}

\author{
Taoguang $Q u^{1}$, Qiang Wei ${ }^{1, *}$, Carlos Ordonez ${ }^{1}$, Jennifer Lindline ${ }^{2}$, Michael Petronis ${ }^{2}$, \\ Marina S. Fonari ${ }^{1,3}$ and Tatiana Timofeeva ${ }^{1, *}$ \\ 1 Department of Chemistry, New Mexico Highlands University, Las Vegas, NM 87701, USA; \\ taoguangqu@gmail.com (T.Q.); carloso14@msn.com (C.O.) \\ 2 Environmental Geology Program, Natural Resource Management Department, New Mexico Highlands \\ University, Las Vegas, NM 87701, USA; lindlinej@nmhu.edu (J.L.); mspetro@nmhu.edu (M.P.) \\ 3 Institute of Applied Physics, Chisinau MD 2028, Moldova; fonari.xray@phys.asm.md \\ * Correspondence: qwei@trevisystems.com (Q.W.); tvtimofeeva@nmhu.edu (T.T.)
}

Received: 18 March 2018; Accepted: 5 April 2018; Published: 8 April 2018

check for updates

\begin{abstract}
In order to assess how metal doping affects the luminescence and magnetic properties of anionic Metal-Organic Frameworks (MOFs), seven single-metal doped MOFs $\{\mathrm{M}-\mathrm{Zn}-\mathrm{BTC}\}\left\{\mathrm{Me}_{2} \mathrm{NH}_{2}{ }^{+}\right\}$ $(\mathrm{M}=\mathrm{Co}, \mathrm{Cu}, \mathrm{Ni}, \mathrm{Mn}, \mathrm{Ca}, \mathrm{Mg}, \mathrm{Cd})$ and three dual-metal doped MOFs $\left.\left\{\mathrm{Zn}-\mathrm{M}_{1}-\mathrm{M}_{2}-\mathrm{BTC}\right\} \mathrm{Me}_{2} \mathrm{NH}_{2}{ }^{+}\right\}$ $\left(\mathrm{M}_{1}=\mathrm{Co}, \mathrm{Cu} ; \mathrm{M}_{2}=\mathrm{Ni}, \mathrm{Co}\right)$ were synthesized. Trace amounts of different metals were doped via addition of another metal salt during the synthetic process. All compounds retained the same crystal structure as that of the parent $\{\mathrm{Zn}-\mathrm{BTC}\}\left\{\mathrm{Me}_{2} \mathrm{NH}_{2}{ }^{+}\right\} \mathrm{MOF}$, which was supported by single crystal and powder X-ray diffraction studies. Thermal Gravimetric Analysis (TGA) of these compounds also revealed that all $\mathrm{MOF}$ had similar stability up to $\sim 450{ }^{\circ} \mathrm{C}$. Solid state photoluminescent studies indicated that $\{\mathrm{Zn}-\mathrm{Mn}-\mathrm{BTC}\}\left\{\mathrm{Me}_{2} \mathrm{NH}_{2}{ }^{+}\right\}$, $\left.\mathrm{Zn}-\mathrm{Cd}-\mathrm{BTC}\right\}\left\{\mathrm{Me}_{2} \mathrm{NH}_{2}{ }^{+}\right\}$, and $\{\mathrm{Zn}-\mathrm{Ca}-\mathrm{BTC}\}\left\{\mathrm{Me}_{2} \mathrm{NH}_{2}{ }^{+}\right\}$had a significant red shifting effect compared to the original $\{\mathrm{Zn}-\mathrm{BTC}\}\left\{\mathrm{Me}_{2} \mathrm{NH}_{2}{ }^{+}\right\} \mathrm{MOF}$. Applications of this doping method to other MOF systems can provide an efficient way to tune the luminescence of such systems, and to obtain a desired wavelength for several applications such as sensors and white light LED materials. Because $\mathrm{Zn}, \mathrm{Co}, \mathrm{Cu}, \mathrm{Ni}, \mathrm{Mg}$ have magnetic properties, the effect of the doping metal atom on the magnetism of the $\{\mathrm{Zn}-\mathrm{BTC}\}\left\{\mathrm{Me}_{2} \mathrm{NH}_{2}{ }^{+}\right\}$networks was also studied. To characterize the magnetic behavior of the synthesized MOFs, we conducted low-temperature $(10 \mathrm{~K})$ saturation remanence experiments in a 3 Tesla applied field, with the principal goal of identifying the domain state of the synthesized materials (Zn, Zn-Co, Zn-Cu-Co, Zn-Cu-Ni, Zn-Mg, Zn-Mn, Zn-Ni-Co, $\mathrm{Zn}-\mathrm{Ni}$ ). During room/low temperature saturation magnetization experiments, $\mathrm{Zn}, \mathrm{Zn}-\mathrm{Co}, \mathrm{Zn}-\mathrm{Cu}-\mathrm{Co}$, and $\mathrm{Zn}-\mathrm{Cu}-\mathrm{Ni}$ systems yielded data indicative of superparamagnetic behavior, yet during zero field and field cooled experiments Zn-Co showed a slight paramagnetic effect, $\mathrm{Zn}$ showed no temperature dependence on warming and $\mathrm{Zn}-\mathrm{Cu}-\mathrm{Co}$ and $\mathrm{Zn}-\mathrm{Cu}-\mathrm{Ni}$ demonstrated only a slight temperature dependence on warming. These behaviors are consistent with ferromagnetic ordering. Zero field and field cooled experiments indicate that $\mathrm{Zn}-\mathrm{Mg}$ and $\mathrm{Zn}-\mathrm{Ni}$ have a ferromagnetic ordering and $\mathrm{Zn}-\mathrm{Mn}$ and $\mathrm{Zn}-\mathrm{Ni}$-Co show paramagnetic ordering behavior.
\end{abstract}

Keywords: MOFs; metal doping; fluorescence; magnetic ordering behavior

\section{Introduction}

Metal-Organic Frameworks (MOFs) are among some of the most versatile and useful synthetic materials. MOFs can be created through the chemical reaction between metal ions and organic ligands [1,2]. Built from metal clusters coordinated to organic ligands, these types of materials have demonstrated an almost unlimited number of possible structures, displaying complex frameworks 
and beautiful topologies [3]. This variability has allowed MOFs to be integrated into many different types of applications and research fields. Originally designed to be gas storage materials [4], these compounds have also been shown to have other properties by incorporating different types of ligands and metals into their frameworks. Today, MOFs are being utilized as magnetic $[5,6]$ and optical materials [7], bio-chemical sensors [8,9], and even as drug delivery agents [10].

One particular property that has gained much attention recently in the research community is the luminescent property that certain MOFs possess $[11,12]$. MOFs display a wide range of luminescent behaviors resulting from the multifaceted natures of their structures [13-16] and have already revealed many useful applications such as small molecule organic explosives and volatile organic compounds capture $[17,18]$.

The origins of MOF luminosity include the linker, the coordinated metal ions and guest molecules. Often luminescent MOFs incorporate $\pi$-conjugated organic luminophores as the ligands because of their rigid backbone structure, and their free electrons, giving them the ability to emit [19]. One common way to produce metal-based emissions is to incorporate lanthanide metal ions within the framework [20]. Coupling these metal ions with rigid $\pi$-conjugated organic ligands induces an energy transfer, known as the "antenna effect", that allows the MOF to display the distinctive lanthanide emission. Alternatively, applying $\mathrm{Mn}(\mathrm{II})$ as the metal ion for the construction of the framework can bring a significant change to the photoluminescence of the framework [21]. In a study of five-coordinated Mn(II) polymer [Mn(Hbidc) $]_{n}$ (Hbidc = 1H-Benzimidazole-5,6-dicarboxylate) [21], the photoluminescence of the free organic ligand had an emission at $474 \mathrm{~nm}$, while the framework displayed an emission at $726 \mathrm{~nm}$. This result suggests that the framework's emission does not originate from the ligand itself, but from the metal-to-ligand charge transfer (MLCT) emission [21]. Thus, these two strategies have been applied to the construction of MOFs with the tunable luminescent properties of the resulting framework [22]. For the most part, $d^{10}$ transition metals, such as zinc and cadmium, are the preferred metal ions for the production of MOF luminescence since they possess a completely filled $d$ orbital and as so usually do not interfere with the nature of the ligand-centered electron transitions, allowing for the emission of the ligand to occur. Moreover, transition metals are significantly cheaper compared to emitting metals (e.g., lanthanides). On the other hand, the first-row transition metals $(\mathrm{V}, \mathrm{Cr}, \mathrm{Mn}, \mathrm{Fe}, \mathrm{Co}, \mathrm{Ni}$ and $\mathrm{Cu}$ ) have contributed significantly to developing porous molecular magnets. Hitherto, a lot of multifunctional MOF materials with magnetic properties have been reported [5,6,23-29]. Recently, magnetism has been introduced within MOFs, named magnetic metal-organic frameworks (MMOFs), through the use of paramagnetic $3 \mathrm{~d}$ transition metal nodes along with suitable organic linkers [5,30,31]. The coordination polymers based on $3 \mathrm{~d}-4 \mathrm{f}$ clusters of transition metals, especially lanthanide metals as potential single molecular magnets (SMM), are the focus of numerous studies. For instance, Zheng et al. (2009) reported a MOF compound, $\mathrm{Dy}_{2} \mathrm{Mn}_{3}(\mathrm{ndc})_{6}$ (bipy) ${ }_{2}$ (where $\mathrm{H}_{2} \mathrm{ndc}=$ 2,6-naphthalenedicarboxylic acid, bipy $=2,2^{\prime}$-pyridine) containing a $\mathrm{Mn}^{\mathrm{II}}$-Dy ${ }^{\mathrm{III}}(3 \mathrm{~d}-4 \mathrm{f})$ mixed-metal five nuclear cluster $\left(\mathrm{Dy}_{2} \mathrm{Mn}_{3}\right.$ cluster), which exhibited ferromagnetism [32]. Recent interests are focused on 'dynamic MOFs' and evaluation of the factors that allow tuning their magnetic properties [31]. Due to the sensitivity of exchange interactions to subtle structural variations, even the delicate changes in the MMOF's structures such as the sorption/desorption of guest molecules, affecting both the ligand and the metal coordination environment, result in different magnetic behavior. For example, Ouellette et al. (2009) reported a hydrolytically and thermally stable microporous material $\left[\mathrm{Co}_{2}-\left(\mathrm{H}_{0.67} \mathrm{bdt}\right)_{3}\right] \cdot 20 \mathrm{H}_{2} \mathrm{O}$ $\left[\mathrm{H}_{2} \mathrm{bdt}=5,5^{\prime}\right.$-(1,4-phenylene $)$ bis $(1 \mathrm{H}$-tetrazole $\left.)\right]$ that exhibits single-chain magnetism and reversible changes in magnetism upon desolvation and resolvation [33]. Another example is the family of porous magnets, metal(II) formates with the general formula $\left[\mathrm{M}_{3}(\mathrm{HCOO})_{6}\right]$, where $\mathrm{M}=\mathrm{Mn}, \mathrm{Fe}, \mathrm{Co}$, or $\mathrm{Ni}$. Despite the lack of changes in the diamondoid framework upon guest sorption, these compounds exhibit ferromagnetic ordering with a guest dependent critical temperature, which might be due to the modification of the host-guest hydrogen-bonding network [31]. An in situ doping strategy was successfully applied by Li et al. (2014) to tune the magnetic behavior and induce fluorescence signal 
mutation of a spindle heptanuclear zinc cluster-based MOF, by only $\mathrm{Co}(\mathrm{II})$-doping of this structure without modifying its structural composition [18]. The $\mathrm{Co}^{\mathrm{II}}$-doped $\mathrm{Zn}-\mathrm{MOF},\left\{\left[\mathrm{Zn}_{7}(\mathrm{OH})_{8}(\mathrm{dta})_{3}\right] \cdot \mathrm{H}_{2} \mathrm{O}\right\}_{\mathrm{n}}$ (where $\mathrm{dta}^{2-}=9,10$-ditetrazolateanthracene) exhibits spin-canted antiferromagnetism and weaker fluorescence properties compared to its parent Zn-MOF [34]. These results further highlighted the importance of the metal doping for tuning material properties.

The combination of carboxylate and zinc ions, which is the most common coordination pair in the reported MOFs, motivated our own research in this field [35-40]. Recently [41], we have reported a series of 13 anionic MOFs constructed from $\mathrm{Zn}^{2+}$ cation with 1,3,5-benzenetricarboxylate (BTC) organic anions that revealed tunable fluorescence controlled by the included counter-cations. We examined the influence of various counter-cations such as $\mathrm{NH}_{4}{ }^{+}, \mathrm{MeNH}_{3}{ }^{+}, \mathrm{Me}_{2} \mathrm{NH}_{2}{ }^{+}, \mathrm{Et}_{3} \mathrm{NH}^{+}$, and $n-\mathrm{Bu}_{4} \mathrm{~N}^{+}$ to observe the structural changes of the anionic Zn-BTC connectivity within the frameworks and the varied fluorescence of the corresponding MOFs. Of the reported $13 \mathrm{MOFs}$ with different topologies, the $3 \mathrm{D}$ coordination network $\{\mathrm{Zn}-\mathrm{BTC}\}\left\{\mathrm{Me}_{2} \mathrm{NH}_{2}{ }^{+}\right\}$with the rutile topology that was previously reported by two scientific groups [42-44], revealed the highest yield (77\%) in our synthetic conditions. Figure 1 shows the metal cluster and crystal structure of the $\{\mathrm{Zn}-\mathrm{BTC}\}\left\{\mathrm{Me}_{2} \mathrm{NH}_{2}{ }^{+}\right\}$system without doping.



(a)

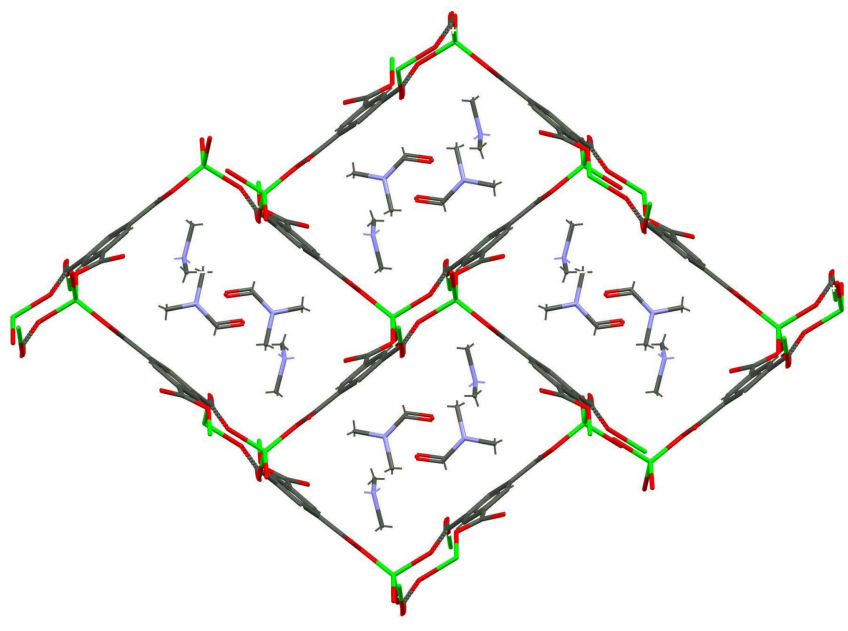

(b)

Figure 1. Crystal structure of $\{\mathrm{Zn}-\mathrm{BTC}\}\left\{\mathrm{Me}_{2} \mathrm{NH}_{2}{ }^{+}\right\}$. (a) The $\left[\mathrm{Zn}_{2}(\mu-\mathrm{OOC})\right]_{2}$ structural motif. H-atoms are omitted for clarity; (b) The fragment of crystal packing of the $\{\mathrm{Zn}-\mathrm{BTC}\}\left\{\mathrm{Me}_{2} \mathrm{NH}_{2}{ }^{+}\right\} \mathrm{MOF}$ system ( $\mathrm{Zn}=$ green, $\mathrm{O}=$ red, $\mathrm{C}=$ grey, $\mathrm{N}=$ blue, $\mathrm{H}=$ white).

The good reproducibility and sufficient yield motivated our choice to dope this system, \{Zn-BTC $\left\{\mathrm{Me}_{2} \mathrm{NH}_{2}{ }^{+}\right\}$, with trace amounts of different metals to observe how this doping affects the framework structure, the luminescence, and magnetic properties. Herein, we report the synthesis, characterization, magnetic ordering behavior, and solid state photoluminescence analysis of single-metal doping MOF systems, $\{\mathrm{Zn}-\mathrm{M}-\mathrm{BTC}\}\left\{\mathrm{Me}_{2} \mathrm{NH}_{2}{ }^{+}\right\}(\mathrm{M}=\mathrm{Co}, \mathrm{Cu}, \mathrm{Ni}, \mathrm{Mn}, \mathrm{Ca}, \mathrm{Mg}, \mathrm{Cd})$ and dual-metal doping systems, $\left\{\mathrm{Zn}-\mathrm{M}_{1}-\mathrm{M}_{2}-\mathrm{BTC}\right\}\left\{\mathrm{Me}_{2} \mathrm{NH}_{2}{ }^{+}\right\}\left(\mathrm{M}_{1}=\mathrm{Co}, \mathrm{Cu} ; \mathrm{M}_{2}=\mathrm{Ni}, \mathrm{Co}\right)$.

\section{Experimental Section}

\subsection{Materials}

All of the chemicals utilized within this study were used as received without further purification, including $\mathrm{Zn}\left(\mathrm{NO}_{3}\right)_{2} \cdot 6 \mathrm{H}_{2} \mathrm{O}(98 \%$, Sigma Aldrich, St. Louis, $\mathrm{MO}, \mathrm{USA}), \mathrm{Co}\left(\mathrm{NO}_{3}\right)_{2} \cdot 6 \mathrm{H}_{2} \mathrm{O}(98.0 \%$, Baker Analyzed, Center Valley, PA, USA), $\mathrm{Cu}\left(\mathrm{NO}_{3}\right)_{2} \cdot 2.5 \mathrm{H}_{2} \mathrm{O}\left(98.0 \%\right.$, Baker Analyzed), $\mathrm{Ni}\left(\mathrm{NO}_{3}\right)_{2} \cdot 6 \mathrm{H}_{2} \mathrm{O}$ (99.0\%, ACROS Organics, Fisher Scientific, Pittsburgh, PA, USA), $\mathrm{Ca}\left(\mathrm{NO}_{3}\right)_{2} \cdot 4 \mathrm{H}_{2} \mathrm{O}(99.0 \%$, Fisher Chemical Co.), $\mathrm{Mn}\left(\mathrm{NO}_{3}\right)_{2} \cdot 6 \mathrm{H}_{2} \mathrm{O}(98.0 \%$, ACS reagent, ACROS Organics, Fisher Scientific, Pittsburgh, 
PA, USA), $\mathrm{Cd}\left(\mathrm{NO}_{3}\right)_{2} \cdot 4 \mathrm{H}_{2} \mathrm{O}$ (98.0\%, Sigma Aldrich), 1,3,5-benzene-tricarboxylic acid (98.0\% Alfa Aesar, Tewksbury, MA, USA), N,N-dimethylformamide (DMF, anhydrous, DriSolv, Denver, CO, USA).

\subsection{Characterization}

X-ray diffraction data were collected with a Bruker-AXS SMART-APEXII CCD diffractometer (Bruker AXS Inc., Madison, WI, USA, MoK $\alpha, \lambda=0.71073 \AA$ ) at temperature of $215 \mathrm{~K}$. Indexing and refinement of the unit cell parameters were obtained using a random set of reflections collected from one or several series of $0.5^{\circ}$ wide $\omega$-scans, and 364 frames per series that were well distributed in reciprocal space; indexing was performed using APEXII (Fast Fourier Transform method). Powder X-ray diffraction (PXRD) spectra were recorded on a GBC Mini Materials Analyzer powder X-ray diffractometer (GBC Scientific Equipment, Hampshire IL, USA) operating at $35 \mathrm{kV}$ and $30 \mathrm{~mA}$ using a $\mathrm{CuK} \alpha$ radiation $\left(\lambda=1.5418 \AA\right.$ ). The $2 \theta$ angles were recorded from $5^{\circ}$ to $40^{\circ}$. Solid-state photoluminescence analysis was performed on a Shimadzu RF-5301 PC spectrofluorometer Shimadzu Scientific Instruments, Columbia, MD, USA) with a xenon lamp light source at ambient temperature. TGA analyses were carried out on a STA7200 Thermal Analysis System (Hitachi High-Tech Sciences, Woodland, CA, USA) with a nitrogen flow of $100 \mathrm{cc} / \mathrm{min}$. The temperature range was from $30^{\circ} \mathrm{C}$ to $500{ }^{\circ} \mathrm{C}$ at heating rate of $10{ }^{\circ} \mathrm{C} / \mathrm{min}$.

\subsection{Magnetic Experiments}

To characterize the magnetic ordering behavior of the synthesized materials, remanence experiments using a Quantum Design 7-Tesla magnetic property measurement system (MPMS) were conducted at the NMHU Paleomagnetic-Rock Magnetic laboratory. The MPMS experiments are used primarily for magnetic mineral identification based on low-temperature crystallographic transitions (e.g., the Verwey transition [45]) based on the loss or gain of remanence on cooling and warming, and for characterizing particle size distributions. For this study, three experimental set-ups were used: (1) field cooled (FC) and zero-field cooled (ZFC), (2) room temperature and low-temperature saturation isothermal remanent magnetization (RTSIRM and LTSIRM), and (3) ZFC and FC within field remanence on warming (ROW). The FC and ZFC measurements were performed by measuring the remanence on warming from $10 \mathrm{~K}$ to $300 \mathrm{~K}$. The FC remanence was measured on warming after cooling to $10 \mathrm{~K}$ in a $3.0 \mathrm{~T}$ field while the ZFC remanence was measured on warming after cooling to $10 \mathrm{~K}$ in a zero field. For the RTSIRM, the sample was magnetized at room temperature in a $3.0 \mathrm{~T}$ applied field and then the field was turned off. The RTSIRM remanence was then measured on cooling from $300 \mathrm{~K}$ to $10 \mathrm{~K}$. For the LTSIRM, a SIRM was imparted by applying a $3.0 \mathrm{~T}$ applied field at $10 \mathrm{~K}$ and then the field was turned off. The LTSIRM remanence was then measured on warming from $10 \mathrm{~K}$ to $300 \mathrm{~K}$. The within field ROW measurements were performed by first cooling the sample from $300 \mathrm{~K}$ to $10 \mathrm{~K}$ in a zero field (ZFC_ROW) and then measuring on warming to $300 \mathrm{~K}$ in a constant applied field $0.001 \mathrm{~T}$. This was followed by cooling the sample from $300 \mathrm{~K}$ to $10 \mathrm{~K}$ in a constant applied field of $0.001 \mathrm{~T}$. The FC_ROW remanence involves cooling the sample in a constant applied field to $10 \mathrm{~K}$ and remanence was measured on warming from $10 \mathrm{~K}$ to $300 \mathrm{~K}$ within a constant applied field of $0.001 \mathrm{~T}$. To exclude the possibility of ferromagnetic contamination, duplicate experiments on blanks (sample holder only) were conducted.

\subsection{Synthesis}

The optimal conditions of solvothermal synthesis found in [41] were used to obtain single- and dual-metal doped analogues of $\{\mathrm{Zn}-\mathrm{BTC}\}\left\{\mathrm{Me}_{2} \mathrm{NH}_{2}{ }^{+}\right\}$system. All syntheses were performed with $\mathrm{Zn}\left(\mathrm{NO}_{3}\right)_{2} \cdot 6 \mathrm{H}_{2} \mathrm{O}, 1,3,5$-benzenetricarboxylic acid, $\left(\mathrm{H}_{3} \mathrm{BTC}\right)$, and the nitrate salt of the corresponding metal dopant as the starting materials which were dissolved in dimethylformamide (DMF). Reaction conditions of synthesized MOFs for single metal doping $\{\mathrm{Zn}-\mathrm{M}-\mathrm{BTC}\}\left\{\mathrm{Me}_{2} \mathrm{NH}_{2}{ }^{+}\right\}$and dual-metal doping $\left\{\mathrm{Zn}-\mathrm{M}_{1}-\mathrm{M}_{2}-\mathrm{BTC}\right\}\left\{\mathrm{Me}_{2} \mathrm{NH}_{2}{ }^{+}\right\}$systems with different metals are given in Tables 1 and 2 . The solutions were sonicated to produce a homogeneous medium and transferred into either a $25 \mathrm{~mL}$ 
or $125 \mathrm{~mL}$ Teflon-lined autoclave. The autoclave was then placed in an oven set at $150{ }^{\circ} \mathrm{C}$ for 3 days. The autoclave was then taken out of the oven and allowed to cool to room temperature. The crystals were then recovered, washed with fresh DMF, and sonicated. We repeated this operation three times to obtain purified crystals.

Table 1. Summary of reaction conditions for MOF synthesis: single metal doping $\{\mathrm{Zn}-\mathrm{M}-\mathrm{BTC}\}\left\{\mathrm{Me}_{2} \mathrm{NH}_{2}{ }^{+}\right\}$.

\begin{tabular}{|c|c|c|c|c|}
\hline Metal Dopant & $\mathrm{Zn}\left(\mathrm{NO}_{3}\right)_{2} \cdot 6 \mathrm{H}_{2} \mathrm{O}(\mathrm{mmol})$ & $\mathrm{H}_{3}$ BTC (mmol) & Metal Dopant Salt (mmol) & DMF (mL) \\
\hline Co & 2.4 & 2.5 & $\begin{array}{c}\mathrm{Co}\left(\mathrm{NO}_{3}\right)_{2} \cdot 6 \mathrm{H}_{2} \mathrm{O} \\
0.13\end{array}$ & 50 \\
\hline $\mathrm{Cu}$ & 0.47 & 0.5 & $\begin{array}{c}\mathrm{Cu}\left(\mathrm{NO}_{3}\right)_{2} \cdot 2.5 \mathrm{H}_{2} \mathrm{O} \\
0.025\end{array}$ & 10 \\
\hline $\mathrm{Ni}$ & 0.47 & 0.5 & $\begin{array}{c}\mathrm{Ni}\left(\mathrm{NO}_{3}\right)_{2} \cdot 6 \mathrm{H}_{2} \mathrm{O} \\
0.024\end{array}$ & 10 \\
\hline $\mathrm{Mn}$ & 0.47 & 0.5 & $\begin{array}{c}\mathrm{Mn}\left(\mathrm{NO}_{3}\right)_{2} \cdot 4 \mathrm{H}_{2} \mathrm{O} \\
0.024\end{array}$ & 10 \\
\hline $\mathrm{Ca}$ & 2.4 & 2.5 & $\begin{array}{c}\mathrm{Ca}\left(\mathrm{NO}_{3}\right)_{2} \cdot 4 \mathrm{H}_{2} \mathrm{O} \\
0.13\end{array}$ & 50 \\
\hline $\mathrm{Mg}$ & 0.47 & 0.5 & $\begin{array}{c}\mathrm{Mg}\left(\mathrm{NO}_{3}\right)_{2} \cdot 6 \mathrm{H}_{2} \mathrm{O} \\
0.024\end{array}$ & 10 \\
\hline $\mathrm{Cd}$ & 0.47 & 0.5 & $\begin{array}{c}\mathrm{Cd}\left(\mathrm{NO}_{3}\right)_{2} \cdot 4 \mathrm{H}_{2} \mathrm{O} \\
0.026\end{array}$ & 10 \\
\hline
\end{tabular}

(Molar ratio of $\mathrm{Zn}: \mathrm{M}=95: 5$ ).

Table 2. Summary of reaction conditions for MOF synthesis: dual-metal doping $\left\{\mathrm{Zn}-\mathrm{M}_{1}-\mathrm{M}_{2}-\mathrm{BTC}\right\}$ $\left\{\mathrm{Me}_{2} \mathrm{NH}_{2}{ }^{+}\right\}$system, the molar ratio of $\mathrm{Zn}: \mathrm{M}_{1}: \mathrm{M}_{2}=94: 3: 3$.

\begin{tabular}{|c|c|c|c|c|}
\hline Metal Dopant & $\mathrm{Zn}\left(\mathrm{NO}_{3}\right)_{2} \cdot 6 \mathrm{H}_{2} \mathrm{O}(\mathrm{mmol})$ & $\mathrm{H}_{3} \mathrm{BTC}(\mathrm{mmol})$ & Metal Dopant Salt (mmol) & DMF (mL) \\
\hline $\mathrm{Co}, \mathrm{Ni}$ & 2.38 & 2.5 & $\begin{array}{c}\mathrm{Co}\left(\mathrm{NO}_{3}\right)_{2} \cdot 6 \mathrm{H}_{2} \mathrm{O} \\
0.075 \\
\mathrm{Ni}\left(\mathrm{NO}_{3}\right)_{2} \cdot 6 \mathrm{H}_{2} \mathrm{O} \\
0.075\end{array}$ & 50 \\
\hline $\mathrm{Cu}, \mathrm{Ni}$ & 2.38 & 2.5 & $\begin{array}{c}\mathrm{Cu}\left(\mathrm{NO}_{3}\right)_{2} \cdot 2.5 \mathrm{H}_{2} \mathrm{O} \\
0.075 \\
\mathrm{Ni}\left(\mathrm{NO}_{3}\right)_{2} \cdot 6 \mathrm{H}_{2} \mathrm{O} \\
0.075\end{array}$ & 50 \\
\hline $\mathrm{Cu}, \mathrm{Co}$ & 2.38 & 2.5 & $\begin{array}{c}\mathrm{Cu}\left(\mathrm{NO}_{3}\right)_{2} \cdot 2.5 \mathrm{H}_{2} \mathrm{O} \\
0.075 \\
\mathrm{Co}\left(\mathrm{NO}_{3}\right)_{2} \cdot 6 \mathrm{H}_{2} \mathrm{O} \\
0.075\end{array}$ & 50 \\
\hline
\end{tabular}

\section{Results and Discussion}

\subsection{Metal Ion Doping}

Our previous work [41] demonstrated that the better quality crystals with the highest yield were obtained within the $\{\mathrm{Zn}-\mathrm{BTC}\}\left\{\mathrm{Me}_{2} \mathrm{NH}_{2}{ }^{+}\right\}$MOF system. In fact, some of the most popular methods to build luminescent MOFs is to utilize zinc, $\mathrm{H}_{3} \mathrm{BTC}$ and DMF as the building blocks [46-48]. Furthermore, a strategy to dope this crystal system was designed in such a way to allow for luminescence to occur within the structure, and to tune the luminescence of the framework. Starting from a 0.5:0.5:1 ratio of $\mathrm{Zn}\left(\mathrm{NO}_{3}\right)_{2} \cdot 6 \mathrm{H}_{2} \mathrm{O}$ :metal salt dopant: $\mathrm{H}_{3} \mathrm{BTC}$ yielded amorphous products confirmed via X-ray powder diffraction patterns. Photoluminescent studies on these solid materials indicated no luminescence within the systems. As a result, the proportion of zinc to metal dopant was changed to a 0.95:0.05 
ratio. This new synthetic ratio produced good quality crystals of different colors in sufficient quantity, indicating the introduction of the metal dopant within the framework. Figure 2 shows some images taken from each crystal doped with one of the seven metals. All crystals possessed euhedral to subhedral shape, while the color of the crystal changed according to the doping metal.

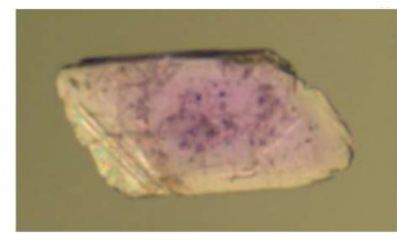

(a)

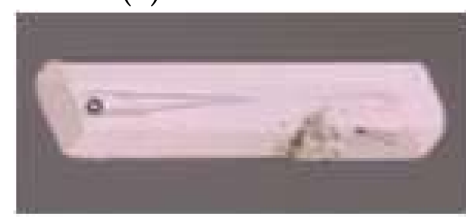

(e)

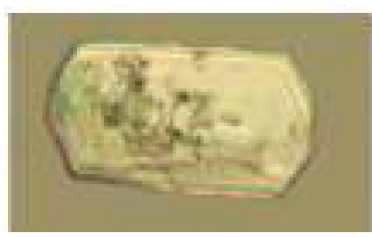

(b)

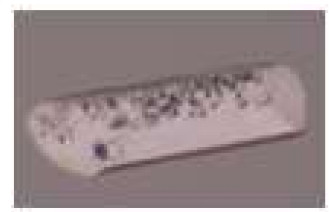

(f)

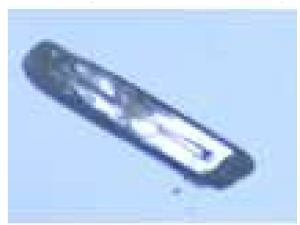

(c)

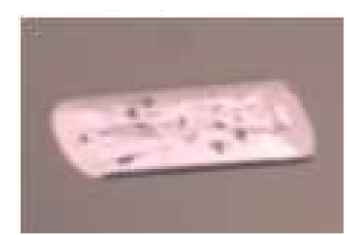

(d)

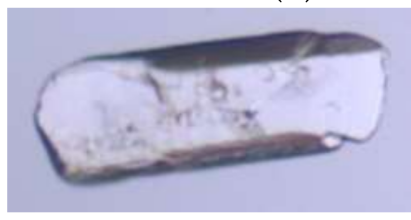

(g)

Figure 2. Color and shape of $\{\mathrm{Zn}-\mathrm{M}-\mathrm{BTC}\}\left\{\mathrm{Me}_{2} \mathrm{NH}_{2}{ }^{+}\right\}$crystals doped with (a) $\mathrm{Co},(\mathbf{b}) \mathrm{Cu},(\mathbf{c}) \mathrm{Ni}$, (d) $\mathrm{Mn}$, (e) $\mathrm{Ca}$, (f) $\mathrm{Mg}$, and (g) $\mathrm{Cd}$.

\subsection{Single Crystal and Powder X-ray Diffraction Analysis}

The comparison of simulated powder pattern of the original $\{\mathrm{Zn}-\mathrm{BTC}\}\left\{\mathrm{Me}_{2} \mathrm{NH}_{2}{ }^{+}\right\} \mathrm{MOF}$ with the experimental plots for all doped bulk materials summarized in Figure 3 shows the retention of crystallinity for the majority of the obtained compounds, with minor redistribution of peaks' intensity. The appearance of several additional but minor peaks indicates the presence of the unidentified impurities in bulk. The worst quality crystals with significant amorphization were observed for the doped systems $\{\mathrm{Zn}-\mathrm{Cu}-\mathrm{BTC}\}\left\{\mathrm{Me}_{2} \mathrm{NH}_{2}\right\},\{\mathrm{Zn}-\mathrm{Cu}-\mathrm{Ni}-\mathrm{BTC}\}\left\{\mathrm{Me}_{2} \mathrm{NH}_{2}\right\}$ and $\{\mathrm{Zn}-\mathrm{Co}-\mathrm{Cu}-\mathrm{BTC}\}\left\{\mathrm{Me}_{2} \mathrm{NH}_{2}\right\}$. In general, our results pointed out that a reasonable ratio for dopant was found for both single or dual-metal doping, and the framework of the original $\{\mathrm{Zn}-\mathrm{BTC}\}\left\{\mathrm{Me}_{2} \mathrm{NH}_{2}{ }^{+}\right\}$MOF was maintained.
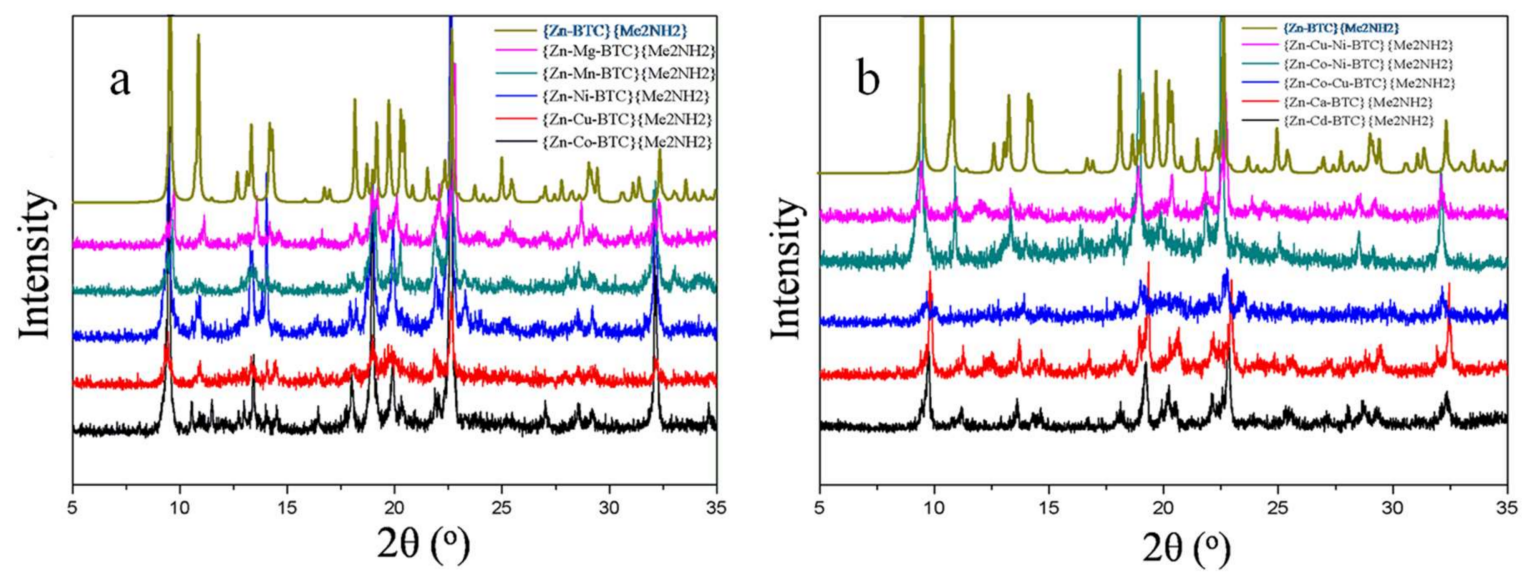

Figure 3. Powder pattern comparison of metal doped system and $\{\mathrm{Zn}-\mathrm{BTC}\}\left\{\mathrm{Me}_{2} \mathrm{NH}_{2}{ }^{+}\right\}$simulated pattern obtained from single crystal X-ray data (marsh line) for single-metal doped (a) and dual-metal doped (b) systems.

The preliminary single crystal X-ray study for the best-quality selected crystals revealed that all 10 crystals had the same monoclinic crystal system, with a $P 2_{1} / n$ space group, and the same unit cell parameters as the parent $\{\mathrm{Zn}-\mathrm{BTC}\}\left\{\mathrm{Me}_{2} \mathrm{NH}_{2}{ }^{+}\right\} \mathrm{MOF}$ [41-44]. The full list of crystal parameters for 
the original $\{\mathrm{Zn}-\mathrm{BTC}\}\left\{\mathrm{Me}_{2} \mathrm{NH}_{2}{ }^{+}\right\}$MOF and for all systems (including single-metal and dual-metal doped solids) is given in Table 3. These results demonstrated that the synthesized doped systems with the 0.95:0.05 ratio of zinc to metal dopant and 0.94:0.03:0.03 ratio of zinc to two metal dopants did not change the unit cell and a sequence the crystal packing of the framework structure. However, the changes in color and in the emission wavelength for different crystals do indicate the incorporation of the dopant within the framework.

Table 3. Crystallographic low temperature data for doped MOFs $\{\mathrm{M}-\mathrm{Zn}-\mathrm{BTC}\}\left\{\mathrm{Me}_{2} \mathrm{NH}_{2}{ }^{+}\right\}$.

\begin{tabular}{cccccc}
\hline & $\boldsymbol{a}(\AA)$ & $\boldsymbol{b}(\AA)$ & $\boldsymbol{c}(\AA)$ & $\boldsymbol{\beta}\left(^{\circ}\right)$ & Volume $\left(\AA^{3}\right)$ \\
\hline no doping & $9.473(5)$ & $16.023(9)$ & $11.107(6)$ & $98.335(8)$ & $1668(3)$ \\
$\mathrm{Cd}$ & $9.481(3)$ & $16.013(4)$ & $11.098(3)$ & $98.351(3)$ & $1667(1)$ \\
$\mathrm{Cu}$ & $9.466(6)$ & $15.998(11)$ & $11.100(7)$ & $98.237(8)$ & $1663(3)$ \\
$\mathrm{Mg}$ & $9.499(5)$ & $16.057(8)$ & $11.124(6)$ & $98.692(7)$ & $1677(3)$ \\
$\mathrm{Ca}$ & $9.474(3)$ & $16.013(5)$ & $11.110(4)$ & $98.260(4)$ & $1668(2)$ \\
$\mathrm{Co}$ & $9.473(4)$ & $16.018(7)$ & $11.128(5)$ & $98.251(5)$ & $1671(2)$ \\
$\mathrm{Ni}$ & $9.482(4)$ & $16.028(7)$ & $11.129(5)$ & $98.198(6)$ & $1674(2)$ \\
$\mathrm{Mn}$ & $9.458(4)$ & $16.067(7)$ & $11.099(5)$ & $98.838(6)$ & $1667(2)$ \\
$\mathrm{Ni}, \mathrm{Co}$ & $9.476(3)$ & $16.017(6)$ & $11.107(4)$ & $98.311(5)$ & $1668(2)$ \\
$\mathrm{Cu}, \mathrm{Ni}$ & $9.498(7)$ & $16.069(10)$ & $11.158(8)$ & $98.281(8)$ & $1685(3)$ \\
$\mathrm{Cu}, \mathrm{Co}$ & $9.499(4)$ & $16.057(8)$ & $11.154(5)$ & $98.221(6)$ & $1684(2)$ \\
\hline
\end{tabular}

\subsection{Thermal Gravimetric Analysis}

TGA analyses for the $\{\mathrm{Zn}-\mathrm{M}-\mathrm{BTC}\}\left\{\mathrm{Me}_{2} \mathrm{NH}_{2}{ }^{+}\right\}(\mathrm{M}=\mathrm{Co}, \mathrm{Cu}, \mathrm{Ni}, \mathrm{Mn}, \mathrm{Ca}, \mathrm{Mg}, \mathrm{Cd})$ systems were performed to investigate the thermal stability of the crystals with metal doping. All seven crystals showed very similar TGA curves as seen in Figures 4 and 5. All seven crystals demonstrated weight loss starting between $30^{\circ} \mathrm{C}$ to $50^{\circ} \mathrm{C}$. This was most probably due to elimination of moisture adsorbed together with DMF solvent within the channels of the MOFs. In accordance with the literature [43], two successive processes can be assigned to the consecutive elimination of DMF (from $10 \%$ to $25 \%$ loss) and hydrogen bonded dimethyl ammonium within the channels of the framework (slow weight loss of about $10 \%$ to $15 \%$ ). These two evaluations were done approximately using the formula weight of the original $\{\mathrm{Zn}-\mathrm{BTC}\}\left\{\mathrm{Me}_{2} \mathrm{NH}_{2}{ }^{+}\right\}$system taking into consideration that the mass portion of doped metal incorporated within the framework was negligible. The frameworks remained stable with no weight loss within the temperature range of $150{ }^{\circ} \mathrm{C}-275{ }^{\circ} \mathrm{C}$. Another weight loss (about $10 \%$ ) was detected in the temperature range of $275^{\circ} \mathrm{C}-325^{\circ} \mathrm{C}$ and was attributed to probable framework collapse. Finally, all solids showed thermal stability from $325^{\circ} \mathrm{C}-450^{\circ} \mathrm{C}$ until total decomposition of the frameworks which was observed at temperatures above $450{ }^{\circ} \mathrm{C}$. From the TGA curves, it is apparent that all seven crystals had a similar thermal stability since they all shared the same structure, as well as the same type of guest molecules within the framework. On the other hand, three frameworks (Figure 4) showed differences in the amount of guest molecules released within the first 20 degrees of heating as compared to the other four frameworks (Figure 5). $\{\mathrm{Zn}-\mathrm{Co}-\mathrm{BTC}\}\left\{\mathrm{Me}_{2} \mathrm{NH}_{2}{ }^{+}\right\}$, $\{\mathrm{Zn}-\mathrm{Cd}-\mathrm{BTC}\}\left\{\mathrm{Me}_{2} \mathrm{NH}_{2}{ }^{+}\right\}$, and $\{\mathrm{Zn}-\mathrm{Ca}-\mathrm{BTC}\}\left\{\mathrm{Me}_{2} \mathrm{NH}_{2}{ }^{+}\right\}$only had a $10 \%$ weight loss at about $50{ }^{\circ} \mathrm{C}$, while the rest of the frameworks had about $15 \%$ to $25 \%$. Currently we are not certain why frameworks doped with $\mathrm{Co}, \mathrm{Cd}$, and $\mathrm{Ca}$ had such a slow release of the DMF guest solvent. We speculate that these metals somehow interact with the guest molecules, having stronger bonding affinity to the guest molecules and thus preventing their leaving the channels. The other possibility might be the activation of these frameworks, accompanied by the loss of DMF and dimethylammonium cations in their deprotonated form due to the proton transfer to the anionic framework [43], with the decomposition of the framework not occurring until temperatures were above $450{ }^{\circ} \mathrm{C}$. 


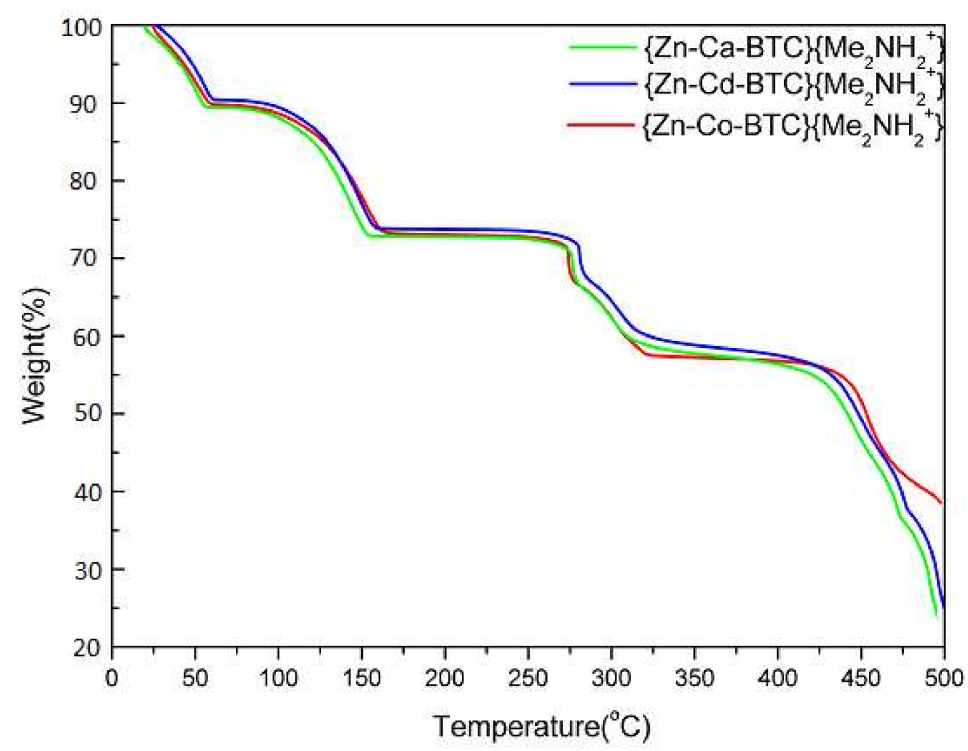

Figure 4. TGA curves of $\{\mathrm{Zn}-\mathrm{M}-\mathrm{BTC}\}\left\{\mathrm{Me}_{2} \mathrm{NH}_{2}{ }^{+}\right\} \mathrm{MOF}(\mathrm{M}=\mathrm{Co}, \mathrm{Cd}, \mathrm{Ca})$.



Figure 5. TGA curves of $\{\mathrm{Zn}-\mathrm{M}-\mathrm{BTC}\}\left\{\mathrm{Me}_{2} \mathrm{NH}_{2}{ }^{+}\right\} \mathrm{MOF}(\mathrm{M}=\mathrm{Cu}, \mathrm{Ni}, \mathrm{Mn}, \mathrm{Mg})$.

\subsection{Effects of Metal Doping on Photoluminescence}

A comparison between the emission peaks of all of the doped frameworks and the emission peak of the original MOF under the same excitation wavelength of $268 \mathrm{~nm}$ revealed that doping the framework with a different metal other than zinc can actually tune the luminescence of the MOF (Figure 6). When compared to the emission of the $\{\mathrm{Zn}-\mathrm{BTC}\}\left\{\mathrm{Me}_{2} \mathrm{NH}_{2}{ }^{+}\right\} \mathrm{MOF}$ given at a wavelength of $395 \mathrm{~nm},\{\mathrm{Zn}-\mathrm{Ni}-\mathrm{BTC}\}\left\{\mathrm{Me}_{2} \mathrm{NH}_{2}{ }^{+}\right\},\{\mathrm{Zn}-\mathrm{Cu}-\mathrm{BTC}\}\left\{\mathrm{Me}_{2} \mathrm{NH}_{2}{ }^{+}\right\},\{\mathrm{Zn}-\mathrm{Co}-\mathrm{BTC}\}\left\{\mathrm{Me}_{2} \mathrm{NH}_{2}{ }^{+}\right\}$, all had emissions with wavelengths at $375 \mathrm{~nm}, 385 \mathrm{~nm}, 410 \mathrm{~nm}$ respectively. These emissions can be attributed to ligand-to-metal charge transfer (LMCT) between the BTC ligand and the metal cluster. From these results, it is apparent that the paramagnetic metal ions like $\mathrm{Cu}, \mathrm{Ni}, \mathrm{Co}$ elements do not have a significant effect on the position of the emission maxima [34]. Alternatively, $\{\mathrm{Zn}-\mathrm{Mg}-\mathrm{BTC}\}\left\{\mathrm{Me}_{2} \mathrm{NH}_{2}{ }^{+}\right\}$, $\{\mathrm{Zn}-\mathrm{Cd}-\mathrm{BTC}\}\left\{\mathrm{Me}_{2} \mathrm{NH}_{2}{ }^{+}\right\},\{\mathrm{Zn}-\mathrm{Mn}-\mathrm{BTC}\}\left\{\mathrm{Me}_{2} \mathrm{NH}_{2}{ }^{+}\right\}$and $\{\mathrm{Zn}-\mathrm{Ca}-\mathrm{BTC}\}\left\{\mathrm{Me}_{2} \mathrm{NH}_{2}{ }^{+}\right\}$showed emission peaks centered at $445 \mathrm{~nm}, 470 \mathrm{~nm}, 480 \mathrm{~nm}$, and $495 \mathrm{~nm}$ respectively. This red shifting in the spectra is 
often attributed to the metal-to-ligand charge transfer (MLCT) transitions in which the metal clusters donate energy to the BTC ligand. Out of the four above mentioned doped frameworks, Ca had the greatest red shifting effect probably arising from a greater interaction between the full orbitals of zinc and calcium with the ligand. Thus, doping other frameworks with $\mathrm{Mg}, \mathrm{Mn}, \mathrm{Ca}$, or $\mathrm{Cd}$ could lead to the red shifting of the framework's emission, effectively tuning the luminescence. The maximum emission wavelength obtained in our experiments was $495 \mathrm{~nm}$ (green light spectrum). However, we argue that we can simulate white light fluorescence by combining yellow light $(570-590 \mathrm{~nm})$ and blue light (415-495 nm) wavelengths. Thus, we changed the cations in this system by using AMIM (1-allyl-3-methylimidazolium) and BMIM (1-butyl-3-methylimidazolium) ions to replace the $\mathrm{Me}_{2} \mathrm{NH}_{2}{ }^{+}$ion and dope with Cd to produce a larger red shift. AMIM and BMIM ions have the largest red shifts compared with other cations, based on the initial work in our group [41], and as predicted, the green-yellow light was obtained successfully. Figure 7 shows the corresponding CIE chromaticity diagram of the $\{\mathrm{Zn}-\mathrm{M}-\mathrm{BTC}\}\{$ Cation $\}$ MOF phosphors with different doping metals and two kinds of cations. Therefore, the different photoluminescence colors can be realized from blue, blue-green, green to green-yellow via doping different metal ions and adjusting the cations of the original $\{\mathrm{Zn}-\mathrm{BTC}\}\left\{\mathrm{Me}_{2} \mathrm{NH}_{2}{ }^{+}\right\}$framework.


Figure 6. Photoluminescence emission of $\{\mathrm{Zn}-\mathrm{M}-\mathrm{BTC}\}\left\{\mathrm{Me}_{2} \mathrm{NH}_{2}{ }^{+}\right\}$(a) and $\{\mathrm{Zn}-\mathrm{Cd}-\mathrm{BTC}\}\{\mathrm{AMIM} / \mathrm{BMIM}\}$ in comparison with $\{\mathrm{Zn}-\mathrm{M}-\mathrm{BTC}\}\left\{\mathrm{Me}_{2} \mathrm{NH}_{2}{ }^{+}\right\}$(b) MOF systems registered in ambient conditions. 




Figure 7. CIE chromaticity diagram of $\{\mathrm{Zn}-\mathrm{M}-\mathrm{BTC}\}\{$ Cation $\} \mathrm{MOF}$ system: (A) $\{\mathrm{Zn}-\mathrm{Ni}-\mathrm{BTC}\}\left\{\mathrm{Me}_{2} \mathrm{NH}_{2}{ }^{+}\right\}$; (B) $\{\mathrm{Zn}-\mathrm{Mn}-\mathrm{BTC}\}\left\{\mathrm{Me}_{2} \mathrm{NH}_{2}{ }^{+}\right\}$; (C) $\{\mathrm{Zn}-\mathrm{Ca}-\mathrm{BTC}\}\left\{\mathrm{Me}_{2} \mathrm{NH}_{2}{ }^{+}\right\} ;$(D) $\{\mathrm{Zn}-\mathrm{Cd}-\mathrm{BTC}\}\{\mathrm{AMIM}\} ;$ (E) \{Zn-Cd-BTC $\}$ BMIM $\}$.

\subsection{Effects of Metal Doping on Magnetism}

To characterize the magnetic ordering behavior of the synthesized materials, we conducted remanence experiments using a Quantum Design 7-Tesla magnetic property measurement system (MPMS) for eight crystalline solids, that include the original $\{\mathrm{Zn}-\mathrm{BTC}\}\left\{\mathrm{Me}_{2} \mathrm{NH}_{2}{ }^{+}\right\} \mathrm{MOF}$, four single-metal doped systems, $\{\mathrm{Zn}-\mathrm{M}-\mathrm{BTC}\}\left\{\mathrm{Me}_{2} \mathrm{NH}_{2}{ }^{+}\right\}, \mathrm{M}=\mathrm{Co}, \mathrm{Mg}, \mathrm{Mn}, \mathrm{Ni}$, and three dual-metal doped systems, $\{\mathrm{Zn}-\mathrm{Cu}-\mathrm{Co}-\mathrm{BTC}\}\left\{\mathrm{Me}_{2} \mathrm{NH}_{2}{ }^{+}\right\}$， $\left.\left.\mathrm{Zn}-\mathrm{Cu}-\mathrm{Ni}-\mathrm{BTC}\right\}\left\{\mathrm{Me}_{2} \mathrm{NH}_{2}{ }^{+}\right\}, \quad \mathrm{Zn}-\mathrm{Ni}-\mathrm{Co}-\mathrm{BTC}\right\}\left\{\mathrm{Me}_{2} \mathrm{NH}_{2}{ }^{+}\right\}$. Magnetic analysis of the metal doped frameworks revealed that doping the crystalline structure with a different metal changes the magnetic ordering behavior of the MOF (Table 4).

Table 4. Magnetic ordering behavior based on MPMS data.

\begin{tabular}{|c|c|c|}
\hline Sample & RTSIRM-LTSIRM Magnetic Order & Within Field ZFC-FC Magnetic Order \\
\hline $\mathrm{Zn}$ & SP & $\mathrm{FM}^{\#, *}$ \\
\hline $\mathrm{Zn} \mathrm{Co}$ & $\mathrm{SP}$ & Para \\
\hline $\mathrm{Zn} \mathrm{Cu} \mathrm{Co}$ & $\mathrm{SP}^{*}$ & $\mathrm{FM}^{\$}$ \\
\hline $\mathrm{Zn} \mathrm{Cu} \mathrm{Ni}$ & $\mathrm{SP}$ & $\mathrm{FM}^{\$}$ \\
\hline $\mathrm{Zn} \mathrm{Mg}$ & & $\mathrm{FM}^{\#, *}$ \\
\hline $\mathrm{Zn} \mathrm{Mn}$ & & Para \\
\hline Zn Ni Co & & Para \\
\hline $\mathrm{Zn} \mathrm{Ni}$ & & $\mathrm{FM}^{\#}$ \\
\hline
\end{tabular}

* Weak behavior; ${ }^{*}$ no temperature dependence; ${ }^{\$}$ slight temperature dependence; SP-Supermagnetic Order; FM-Ferromagnetic Order; Para-Paramagnetism (lacks magnetic ordering).

\subsection{Remanence Results}

To evaluate the stability of an induced remanence upon cooling and warming, we performed low temperature (LT) cycling ( $300 \mathrm{~K} \rightarrow 10 \mathrm{~K}$ ) of a room temperature (RT) (300 K) saturation isothermal remanence (RTSIRM) and a LT saturation isothermal remanence (LTSIRM) where a saturation IRM 
is imparted at $10 \mathrm{~K}$ and this LT remanence is then measured as the sample warms back to RT $(10 \mathrm{~K} \rightarrow 300 \mathrm{~K})$.

\subsubsection{Superparamagnetic Ordering Behavior}

RT and LT remanence/temperature curves are presented for four materials that show superparamagnetic ordering behavior (Figure 8). In general, the four samples on cooling from $300 \mathrm{~K}$, the RTSIRM showed no decrease or increase in remanence indicating that the magnetic moments of the materials do not have a dependence on temperature and that the zero field in the chamber is very low for all four samples. The large initial remanence on the warming curves is the LTSIRM and does not reflect a paramagnetic component. During the RTSIRM experiment, $\{\mathrm{Zn}-\mathrm{BTC}\}\left\{\mathrm{Me}_{2} \mathrm{NH}_{2}{ }^{+}\right\}$, $\{\mathrm{Zn}-\mathrm{Cu}-\mathrm{Ni}-\mathrm{BTC}\}\left\{\mathrm{Me}_{2} \mathrm{NH}_{2}{ }^{+}\right\}$, and $\{\mathrm{Zn}-\mathrm{Co}-\mathrm{BTC}\}\left\{\mathrm{Me}_{2} \mathrm{NH}_{2}{ }^{+}\right\}$yielded a steady decay of remanence that is almost linear to $300 \mathrm{~K}$ (Figure $8 \mathrm{~A}-\mathrm{C}$ ). $\{\mathrm{Zn}-\mathrm{Cu}-\mathrm{Co}-\mathrm{BTC}\}\left\{\mathrm{Me}_{2} \mathrm{NH}_{2}{ }^{+}\right\}$had a slightly different behavior on cooling from $300 \mathrm{~K}$ with the RTSIRM showing a moderate increase (30\%) in remanence up to $140 \mathrm{~K}$. The remanence then dropped abruptly $(8 \%)$ and on further cooling to $10 \mathrm{~K}$, there was no temperature dependence of the remanence beyond $130 \mathrm{~K}$ (Figure 8D). The application of the LTSIRM for all four samples yielded an initial increase in the remanence. On further warming, the decay of the remanence was almost linear to $300 \mathrm{~K}$ with no inflections indicative of a crystalline phase transition (Figure 8A-D).
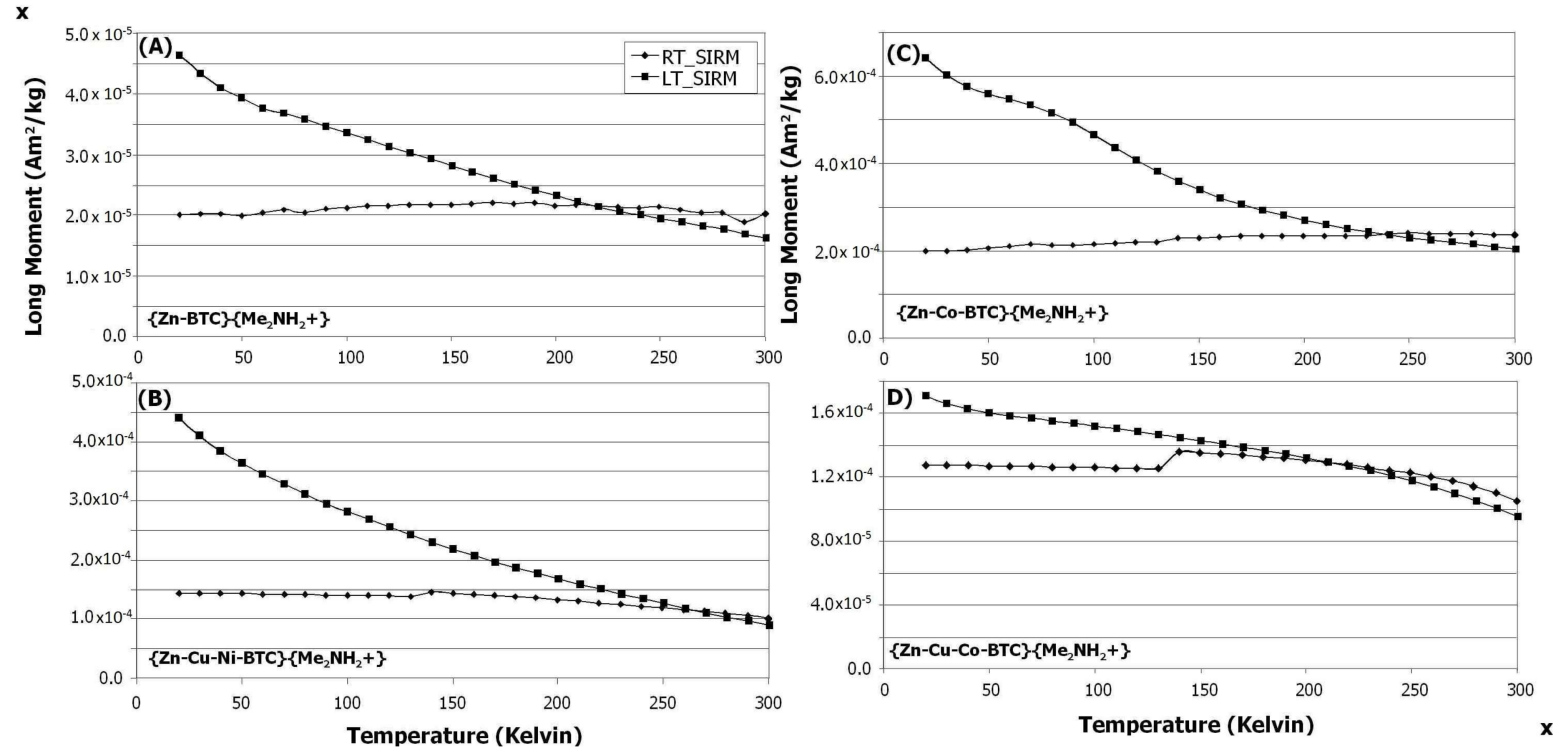

Figure 8. Room temperature saturation isothermal remanent magnetization (RT_SIRM) and low-temperature SIRM (LT_SIRM) experiments for $\{\mathrm{Zn}-\mathrm{BTC}\}\left\{\mathrm{Me}_{2} \mathrm{NH}_{2}{ }^{+}\right\}$(A); $\{\mathrm{Zn}-\mathrm{Cu}-\mathrm{Ni}-\mathrm{BTC}\}$ $\left\{\mathrm{Me}_{2} \mathrm{NH}_{2}{ }^{+}\right\}$(B); $\{\mathrm{Zn}-\mathrm{Co}-\mathrm{BTC}\}\left\{\mathrm{Me}_{2} \mathrm{NH}_{2}{ }^{+}\right\}$(C); $\{\mathrm{Zn}-\mathrm{Cu}-\mathrm{Co}-\mathrm{BTC}\}\left\{\mathrm{Me}_{2} \mathrm{NH}_{2}{ }^{+}\right\}$(D).

Samples yielded demagnetization data consistent with superparamagnetic ordering behavior. On cooling, the RTSIRM showed no decrease or increase in remanence indicating that the magnetic moments of the materials do not have a dependence on temperature. We interpret the near linear remanence behavior with temperature on cooling and the loss of remanence on warming from these four samples to reflect superparamagnetic ordering behavior [49-51].

\subsubsection{Induced Magnetization Data}

For induced magnetization experiments, a sample is cooled in a zero field (ZFC) to $10 \mathrm{~K}$, and the induced sample moment is then measured on warming in the presence of a small (e.g., $0.001 \mathrm{~T}$ ) field (within Field ZFC-FC ROW). This is followed by cooling the sample in the same $0.001 \mathrm{~T}$ field (FC) and again measuring induced sample moment on warming in a $0.001 \mathrm{~T}$ field (Figure 9). The ratio of 
the $\delta \mathrm{FC} / \delta \mathrm{ZFC}$ [52] and the ratio of M1/M5 [53] provides an estimate of the magnetic domain state. The magnetic domain state of the grain is single domain when the $\delta \mathrm{FC} / \delta \mathrm{ZFC}$ ratio is greater than 1 and the M1/M5 ratio is between 1 to $\sim 1.3$. Values less than or equal to 1 are indicative of all other magnetic domain sizes (e.g., multidomain) [52,53]. It is important to note that the $\delta \mathrm{FC} / \delta \mathrm{ZFC}$ and M1/M5 ratios are the best estimate of magnetic domain state but the results are often not $100 \%$ conclusive $[52,53]$.
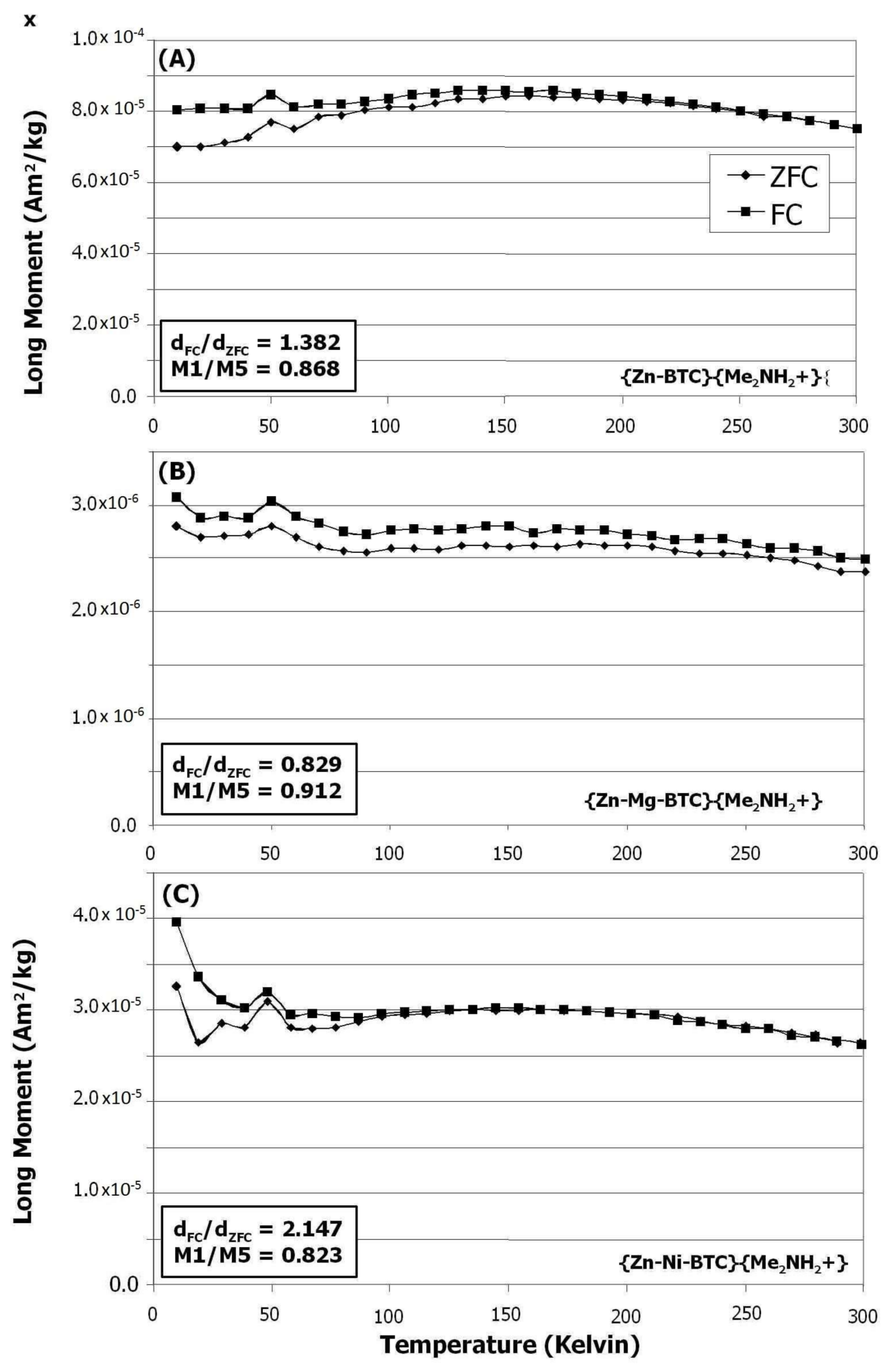

Figure 8. Cont. 
$\mathbf{X}$


Figure 9. Field cooled (FC) and zero-field cooled (ZFC) experimental data within a constant applied field of $0.001 \mathrm{~T}$ remanence on warming (ROW) experiments for $\{\mathrm{Zn}-\mathrm{BTC}\}\left\{\mathrm{Me}_{2} \mathrm{NH}_{2}{ }^{+}\right\}$ (A); $\{\mathrm{Zn}-\mathrm{Mg}-\mathrm{BTC}\}\left\{\mathrm{Me}_{2} \mathrm{NH}_{2}{ }^{+}\right\}$(B); $\{\mathrm{Zn}-\mathrm{Ni}-\mathrm{BTC}\}\left\{\mathrm{Me}_{2} \mathrm{NH}_{2}{ }^{+}\right\}$(C); $\{\mathrm{Zn}-\mathrm{Cu}-\mathrm{Co}-\mathrm{BTC}\}\left\{\mathrm{Me}_{2} \mathrm{NH}_{2}{ }^{+}\right\}$(D); $\{\mathrm{Zn}-\mathrm{Cu}-\mathrm{Ni}-\mathrm{BTC}\}\left\{\mathrm{Me}_{2} \mathrm{NH}_{2}{ }^{+}\right\}$(E). The ratio of the $\delta \mathrm{FC} / \delta \mathrm{ZFC}$ and the ratio of M1/M5 provided an estimate of the magnetic domain state.

\subsubsection{Ferromagnetic Ordering Behavior: Little Field Dependence on Warming}

On warming, $\{\mathrm{Zn}$-BTC $\left.\} \mathrm{Me}_{2} \mathrm{NH}_{2}{ }^{+}\right\}$showed little dependence temperature up to $50 \mathrm{~K}$ and on further warming through $60 \mathrm{~K}$, the sample increased in remanence followed by a slight drop at $70 \mathrm{~K}$. A steady, albeit slight, increase in remanence from $70 \mathrm{~K}$ to $150 \mathrm{~K}$ was followed by a steady, but minor decrease in remanence from $150 \mathrm{~K}$ to $300 \mathrm{~K}$ (Figure 9A). At $10 \mathrm{~K}$, the FC remanence was slightly higher than the ZFC remanence $(15 \%)$ and the two curves converged at $\sim 200 \mathrm{~K}$. The ratio $\delta \mathrm{FC} / \delta \mathrm{ZFC}$ yielded 1.382 and the M1/M5 yielded 0.868 .

Three samples (Figure 9A-C) showed little to no dependence on temperature indicative of ferromagnetic ordering behavior. $\{\mathrm{Zn}-\mathrm{Mg}-\mathrm{BTC}\}\left\{\mathrm{Me}_{2} \mathrm{NH}_{2}{ }^{+}\right\}$and $\{\mathrm{Zn}-\mathrm{Ni}-\mathrm{BTC}\}\left\{\mathrm{Me}_{2} \mathrm{NH}_{2}{ }^{+}\right\}$yielded similar behaviors on warming for both the ZFC and FC experiments (Figure 9B,C). They both display a drop in remanence from $10 \mathrm{~K}$ to $20 \mathrm{~K}$ followed by little temperature dependence up to $40 \mathrm{~K}$, where there is a slight increase in remanence at $50 \mathrm{~K}$. On further heating, the sample showed a steady decrease 
in remanence from $60 \mathrm{~K}$ to $300 \mathrm{~K}$. The FC remanence is higher than the ZFC remanence $(10-22 \%$, respectively) and for $\{\mathrm{Zn}-\mathrm{Mg}-\mathrm{BTC}\}\left\{\mathrm{Me}_{2} \mathrm{NH}_{2}{ }^{+}\right\}$the two curves did not converge (Figure 9B) while for $\{\mathrm{Zn}-\mathrm{Ni}-\mathrm{BTC}\}\left\{\mathrm{Me}_{2} \mathrm{NH}_{2}{ }^{+}\right\}$, the curves converged at $100 \mathrm{~K}$ (Figure 9C). The ratio $\delta \mathrm{FC} / \delta \mathrm{ZFC}$ yielded 0.829 and the M1/M5 was 0.912 for $\{\mathrm{Zn}-\mathrm{Mg}-\mathrm{BTC}\}\left\{\mathrm{Me}_{2} \mathrm{NH}_{2}{ }^{+}\right\}$and $\delta \mathrm{FC} / \delta \mathrm{ZFC}$ was 2.147 and the M1/M5 yielded 0.823 for $\{\mathrm{Zn}-\mathrm{Ni}-\mathrm{BTC}\}\left\{\mathrm{Me}_{2} \mathrm{NH}_{2}{ }^{+}\right\}$. The lack of strong field dependence for these samples on warming is diagnostic of ferromagnetic ordering behavior [54]. We note that $\mathrm{Zn}(\mathrm{II})$ and $\mathrm{Mg}(\mathrm{II})$ are diamagnetic ions and that they should not display a behavior consistent with ferromagnetic ordering, albeit, as we note, this effect was slight. Otherwise, recent studies for $\mathrm{Zn}_{n} \mathrm{O}_{n}$ clusters and $\mathrm{ZnO}$ nanoparticles indicated the defect induced magnetism in $\mathrm{ZnO}$ clusters even without any transition metal dopants $[55,56]$. The extrapolation of these results to the reported MOF systems can suggest the impact of the defects in MOF structures to achieve and explain the origin of magnetic properties of the reported materials. Although the minor contamination of the sample by a ferromagnetic phase may have occurred which would account for the observed magnetic ordering behavior, it is important to note that repeated experiments on the samples consistently showed minor ferromagnetic ordering behavior. Furthermore, several experiments on blanks (i.e., empty sample holder) revealed no evidence of ferromagnetic contamination on multiple runs within the measurement chamber.

\subsubsection{Ferromagnetic Ordering Behavior: Slight Field Dependence on Warming}

Two samples (Figure 9D,E) yielded a slight field dependence with increasing temperature consistent with ferromagnetic ordering behavior with a weak contribution from paramagnetic or superparamagnetic ordering behavior. On warming, $\{\mathrm{Zn}-\mathrm{Cu}-\mathrm{Co}-\mathrm{BTC}\}\left\{\mathrm{Me}_{2} \mathrm{NH}_{2}{ }^{+}\right\}$showed a steady decrease in remanence from $10 \mathrm{~K}$ to $300 \mathrm{~K}$ (Figure 9D). A slight drop in remanence occurred from $10 \mathrm{~K}$ to $30 \mathrm{~K}$ on both the FC and ZFC experiments. The ZFC remanence was slightly higher than the FC remanence (4\%) and the two curves converged at $190 \mathrm{~K}$. The ratio $\delta \mathrm{FC} / \delta \mathrm{ZFC}$ yielded 0.977 and the M1/M5 yielded 0.981. On warming, $\{\mathrm{Zn}-\mathrm{Cu}-\mathrm{Ni}-\mathrm{BTC}\}\left\{\mathrm{Me}_{2} \mathrm{NH}_{2}{ }^{+}\right\}$yielded a steady decrease in remanence from $10 \mathrm{~K}$ to $300 \mathrm{~K}$ (Figure 9E). The FC remanence was higher than the ZFC remanence $(23 \%)$ and the two curves converged at $260 \mathrm{~K}$. The ratio $\delta \mathrm{FC} / \delta \mathrm{ZFC}$ yielded 0.592 and the M1/M5 yielded 0.815 . The magnetic domain state for these samples was likely multidomain and the minor field dependence for these samples may reflect that some grains showed weak paramagnetic or superparamagnetic ordering behavior. The samples, however, were dominated by a ferromagnetic effect [54].

\subsubsection{Paramagnetic Behavior-Lacks Magnetic Ordering}

For $\{\mathrm{Zn}-\mathrm{Mn}-\mathrm{BTC}\}\left\{\mathrm{Me}_{2} \mathrm{NH}_{2}{ }^{+}\right\}$, both curves yielded near identical behavior on warming from $10 \mathrm{~K}$ to $300 \mathrm{~K}$ (Figure 10A).

The three samples (Figure 10A-C) yielded similar behavior on warming from $10 \mathrm{~K}$ to $300 \mathrm{~K}$. There was a sharp drop between $10 \mathrm{~K}$ and $70 \mathrm{~K}$ and a near linear decrease in remanence from $80 \mathrm{~K}$ to $300 \mathrm{~K}$. A sharp drop occurred on the FC curve at $70 \mathrm{~K}$ and on the ZFC curve at $90 \mathrm{~K}$. A similar drop in remanence occurred on the FC curve at $170 \mathrm{~K}$ and at $180 \mathrm{~K}$ on the ZFC curve. On further warming, the FC and ZFC showed an erratic increase and decrease in remanence up $300 \mathrm{~K}$. The shapes of the curves were close to $1 / \mathrm{T}$, indicative of a paramagnetic phase. We modeled each curve as a Curie-Weiss paramagnet with $\mathrm{M}=\mathrm{kH}$ and $\mathrm{k} \propto 1 /(\mathrm{T}-\theta)$, where $\theta$ is the 'paramagnetic Curie constant' (Figure 10B). For (Figure 10A) a straight line was fitted on a plot of $M$ versus $1 /(T-\theta)$ when $\theta$ is $-10 \mathrm{~K}$, for (Figure 10B) it is $0 \mathrm{~K}$, and for (Figure 10C) it is $-5 \mathrm{~K}$. The negative sign of $\theta$ indicates that there is a weak antiferromagnetic interaction (Figure 10A,C). For these data, a straight line was fitted on a plot of $M$ versus $1 /(T-\theta)$ when $\theta$ is $-10 \mathrm{~K}$. The negative sign of $\theta$ indicates that there was a weak antiferromagnetic interaction. The ratio $\delta \mathrm{FC} / \delta Z \mathrm{ZFC}$ yields 1.639 and the M1/M5 yields 0.982. Similar to the previous sample, $\{\mathrm{Zn}-\mathrm{Co}-\mathrm{BTC}\}\left\{\mathrm{Me}_{2} \mathrm{NH}_{2}{ }^{+}\right\}$, both curves yielded near identical behavior on warming from $10 \mathrm{~K}$ to $300 \mathrm{~K}$ with a sharp drop between $10 \mathrm{~K}$ and $50 \mathrm{~K}$ and a near linear decrease in remanence from $60 \mathrm{~K}$ to $300 \mathrm{~K}$. The ratio $\delta \mathrm{FC} / \delta \mathrm{ZFC}$ yielded 0.019 and the M1/M5 yielded 
0.906 (Figure 10C). For $\{\mathrm{Zn}-\mathrm{Ni}-\mathrm{Co}-\mathrm{BTC}\}\left\{\mathrm{Me}_{2} \mathrm{NH}_{2}{ }^{+}\right\}$, both curves yielded near identical behavior on warming from $10 \mathrm{~K}$ to $300 \mathrm{~K}$ with a sharp drop between $10 \mathrm{~K}$ and $70 \mathrm{~K}$ and a near linear decrease in remanence from $80 \mathrm{~K}$ to $300 \mathrm{~K}$. The ratio $\delta \mathrm{FC} / \delta \mathrm{ZFC}$ yielded 1.010 and the M1/M5 yields 0.933 (Figure 10D). We reran the sample $\{\mathrm{Zn}-\mathrm{Mn}-\mathrm{BTC}\}\left\{\mathrm{Me}_{2} \mathrm{NH}_{2}{ }^{+}\right\}$with a slightly different experimental setup. This experiment involved a ZFC-FC without an applied field. The results are nearly identical to the within-field experiment yet the ratio $\delta \mathrm{FC} / \delta \mathrm{ZFC}$ yielded 1.089 and the M1/M5 yielded 1.020.
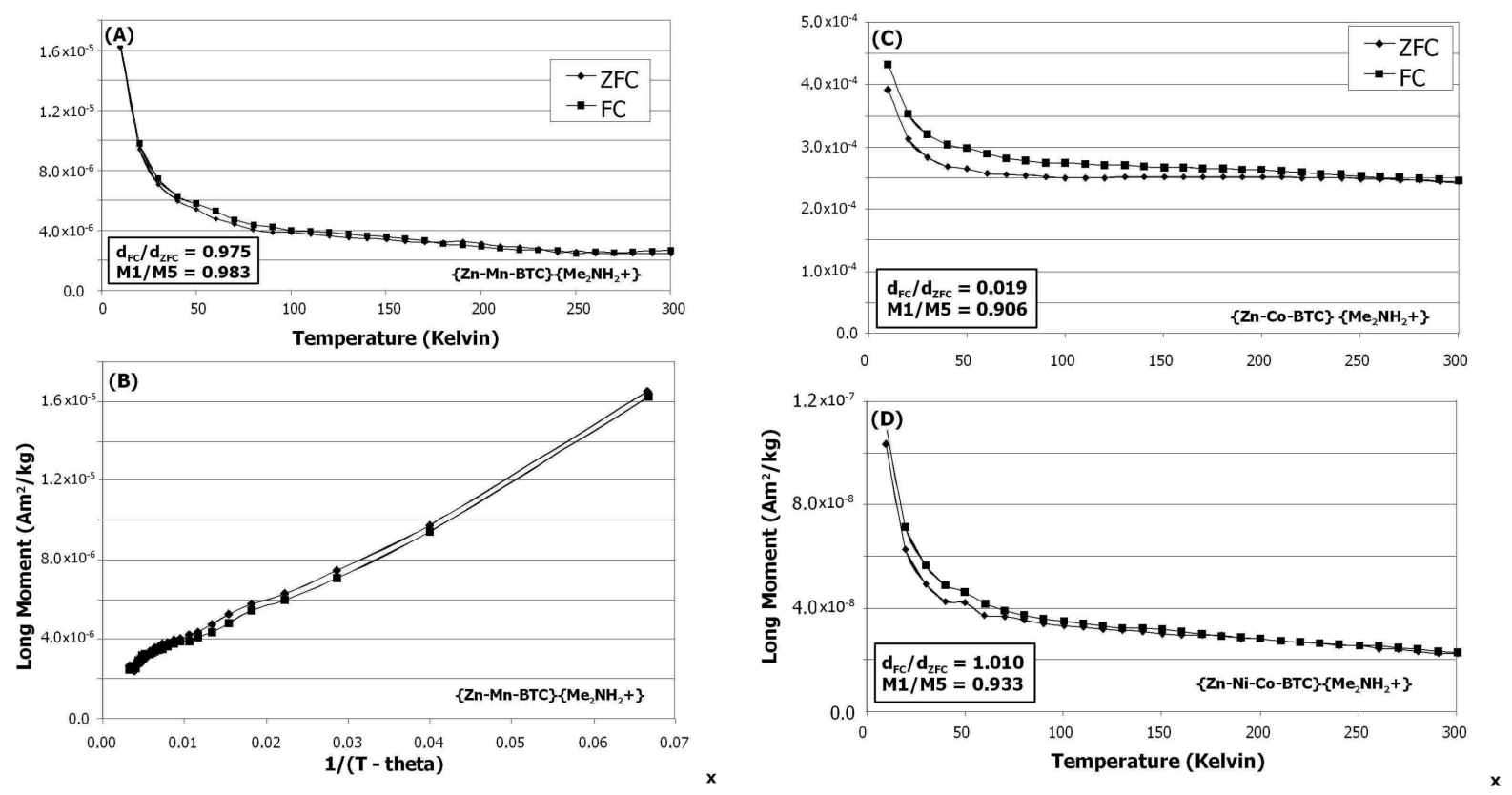

Figure 10. $\mathrm{FC}$ and $\mathrm{ZFC}$ within a constant applied field $0.001 \mathrm{~T}$ ROW experiments for $\{\mathrm{Zn}-\mathrm{Mn}-\mathrm{BTC}\}\left\{\mathrm{Me}_{2} \mathrm{NH}_{2}{ }^{+}\right\}$(A,B); $\{\mathrm{Zn}-\mathrm{Co}-\mathrm{BTC}\}\left\{\mathrm{Me}_{2} \mathrm{NH}_{2}{ }^{+}\right\}$(C); $\{\mathrm{Zn}-\mathrm{Ni}-\mathrm{Co}-\mathrm{BTC}\}\left\{\mathrm{Me}_{2} \mathrm{NH}_{2}{ }^{+}\right\}$(D).

\section{Conclusions}

Ten metal-doped MOF systems including seven single-doped ( $\mathrm{M}=\mathrm{Co}, \mathrm{Cu}, \mathrm{Ni}, \mathrm{Mn}, \mathrm{Ca}, \mathrm{Mg}, \mathrm{Cd})$ and three dual-doped $\left(\left(\mathrm{M}_{1}=\mathrm{Co}, \mathrm{Cu} ; \mathrm{M}_{2}=\mathrm{Ni}, \mathrm{Co}\right)\right.$ solids starting from the original $\{\mathrm{Zn}-\mathrm{BTC}\}\left\{\mathrm{Me}_{2} \mathrm{NH}_{2}{ }^{+}\right\}$ $\mathrm{MOF}$ were synthesized and their structures, photoluminescent and magnetic properties were studied systematically. Doping the $\{\mathrm{Zn}-\mathrm{BTC}\}\left\{\mathrm{Me}_{2} \mathrm{NH}_{2}{ }^{+}\right\}$system with the zinc to metal dopant molar ratios of 0.95:0.05 $\left(\mathrm{Zn}: \mathrm{M}_{1}\right)$ and 0.94:0.03:0.03 $\left(\mathrm{Zn}: \mathrm{M}_{1}: \mathrm{M}_{2}\right)$ did not change the MOFs' structure since the single crystal X-ray analysis showed that the unit cell parameters for all selected best-quality doped single crystals matched to those of the original un-doped system. In bulk, the significant amorphization was observed for the doped systems $\{\mathrm{Zn}-\mathrm{Cu}-\mathrm{BTC}\}\left\{\mathrm{Me}_{2} \mathrm{NH}_{2}\right\},\{\mathrm{Zn}-\mathrm{Cu}-\mathrm{Ni}-\mathrm{BTC}\}\left\{\mathrm{Me}_{2} \mathrm{NH}_{2}\right\}$ and $\{\mathrm{Zn}-\mathrm{Co}-\mathrm{Cu}-\mathrm{BTC}\}\left\{\mathrm{Me}_{2} \mathrm{NH}_{2}\right\}$. TGA analysis revealed that the $\{\mathrm{Zn}-\mathrm{M}-\mathrm{BTC}\}\left\{\mathrm{Me}_{2} \mathrm{NH}_{2}{ }^{+}\right\}(\mathrm{M}=\mathrm{Co}, \mathrm{Cu}, \mathrm{Ni}$, $\mathrm{Mn}, \mathrm{Ca}, \mathrm{Mg}, \mathrm{Cd}$ ) systems exhibited a similar stability and guest diffusion pathway. Furthermore, frameworks doped with $\mathrm{Mg}, \mathrm{Mn}, \mathrm{Ca}$, and $\mathrm{Cd}$ presented significant red shift compared with the emission spectrum of the original $\{\mathrm{Zn}-\mathrm{BTC}\}\left\{\mathrm{Me}_{2} \mathrm{NH}_{2}{ }^{+}\right\} \mathrm{MOF}$ system. This result was attributed to MLCT transitions that occurred between the metal cluster and the BTC ligand. Doping of the parent framework could both retain the crystal structure, and tune the luminescence to achieve a new emission, which was not observed before with the original framework. The introduction of AMIM and BMIM cations to the original framework could effectively further increase the luminescence wavelength. This type of tuning is helpful to integrate these materials into applications such as chemical sensors and white light LED materials for electronic displays and lighting. White light LED materials often need two or more emission wavelengths to achieve white light, and the strategy of tuning the luminescence is an efficient way to accomplish this. Low temperature remanence experiments showed a range of behavior, depending on the experimental set-up, characterized by superparamagnetic ordering for $\mathrm{Zn}$, 
$\mathrm{Zn}-\mathrm{Co}, \mathrm{Zn}-\mathrm{Cu}-\mathrm{Co}, \mathrm{Zn}-\mathrm{Cu}-\mathrm{Ni}$ during room/low temperature saturation magnetization experiments (RTSIRM and LTSIRM). However, during zero field cooled (ZFC) and field cooled (FC) experiments, $\mathrm{Zn}$ does not have a temperature dependence on warming, $\mathrm{Zn}-\mathrm{Cu}-\mathrm{Co}$ and $\mathrm{Zn}-\mathrm{Cu}-\mathrm{Ni}$ demonstrated only a slight temperature dependence on warning, and $\mathrm{Zn}-\mathrm{Mg}$ and $\mathrm{Zn}-\mathrm{Ni}$ systems showed either no remanence dependence or only a slight dependence on temperature. Collectively, these materials are consistent with ferromagnetic ordering, albeit minor. In addition, for the diamagnetic ions $\mathrm{Zn}$ and $\mathrm{Zn}-\mathrm{Mg}$ system that are demonstrating weak ferromagnetism, we cannot rule out the possibility of slight contamination of the material while loading into the instrument. $\mathrm{Zn}-\mathrm{Mn}$ and $\mathrm{Zn}-\mathrm{Ni}-\mathrm{Co}$ exhibited no collective magnetic interactions and were not magnetically ordered, which is indicative of paramagnetic ordering behavior.

Acknowledgments: Authors are grateful for NSF support (DMR-1523611) via PREM program.

Author Contributions: Qiang Wei and Tatiana Timofeeva conceived and designed the experiments, Taoguang Qu, and Carlos Ordonez performed the synthetic and single crystal X-ray experiments, Jennifer Lindline performed the X-ray powder diffraction experiments, Michael Petronis performed the magnetic measurements, Qiang Wei, Michael Petronis, Marina S. Fonari, and Tatiana Timofeeva analyzed the data; all authors took part in writing and discussion of the paper.

Conflicts of Interest: The authors declare no conflict of interest.

\section{References}

1. Kaye, S.S.; Dailly, A.; Yaghi, O.M.; Long, J.R. Impact of preparation and handling on the hydrogen storage properties of $\mathrm{Zn}_{4} \mathrm{O}$ (1,4-benzenedicarboxylate) 3 (MOF-5). J. Am. Chem. Soc. 2007, 129, 14176-14177. [CrossRef] [PubMed]

2. Chae, H.K.; Siberio-Pérez, D.Y.; Kim, J.; Go, Y.; Eddaoudi, M.; Matzger, A.J.; O’Keeffe, M.; Yaghi, O.M. A route to high surface area, porosity and inclusion of large molecules in crystals. Nature 2004, 427, 523-527. [CrossRef] [PubMed]

3. O'Keeffe, M.; Yaghi, O.M. Deconstructing the crystal structures of metal-organic frameworks and related materials into their underlying nets. Chem. Rev. 2012, 112, 675-702. [CrossRef] [PubMed]

4. Getman, R.B.; Bae, Y.S.; Wilmer, C.E.; Snurr, R.Q. Review and Analysis of molecular simulations of methane, hydrogen, and acetylene storage in metal-organic frameworks. Chem. Rev. 2012, 112, 703-723. [CrossRef] [PubMed]

5. Kurmoo, M. Magnetic metal-organic frameworks. Chem. Soc. Rev. 2009, 38, 1353-1379. [CrossRef] [PubMed]

6. Luo, J.; Zhao, Y.; Xu, H.; Kinnibrugh, T.L.; Yang, D.; Timofeeva, T.V.; Daemen, L.L.; Zhang, J.; Bao, W.; Thompson, J.D.; et al. A Novel Helical Double-Layered Cobalt(II)-Organic Framework with Tetranuclear $\left[\mathrm{Co}_{4}\left(\mu_{3}-\mathrm{OH}\right)_{2}\right]$ Clusters Linked by an Unsymmetrical Pyridylbenzoate Ligand. Inorg. Chem. 2007, 46, 9021-9023. [CrossRef] [PubMed]

7. Wang, C.; Zhang, T.; Lin, W. Rational synthesis of noncentrosymmetric metal-organic frameworks for second-order nonlinear optics. Chem. Rev. 2012, 112, 1084-1104. [CrossRef] [PubMed]

8. Kreno, L.E.; Leong, K.; Farha, O.K.; Allendorf, M.; Van Duyne, R.P.; Hupp, J.T. Metal-organic framework materials as chemical sensors. Chem. Rev. 2011, 112, 1105-1125. [CrossRef] [PubMed]

9. Luo, J.; Xu, H.; Liu, Y.; Zhao, Y.; Daemen, L.L.; Brown, C.; Timofeeva, T.V.; Ma, S.; Zhou, H.-C. Hydrogen Adsorption in a Highly Stable Porous Rare-Earth Metal-Organic Framework: Sorption Properties and Neutron Diffraction Studies. J. Am. Chem. Soc. 2008, 130, 9626-9627. [CrossRef] [PubMed]

10. Horcajada, P.; Gref, R.; Baati, T.; Allan, P.K.; Maurin, G.; Couvreur, P.; Férey, G.; Morris, R.E.; Serre, C. Metal-organic frameworks in biomedicine. Chem. Rev. 2012, 112, 1232-1268. [CrossRef] [PubMed]

11. Cui, Y.; Yue, Y.; Qian, G.; Chen, B. Luminescent Functional Metal-Organic Frameworks. Chem. Rev. 2012, 112, 1126-1162. [CrossRef] [PubMed]

12. Zhu, X.-D.; Zhang, K.; Wang, Y.; Long, W.-W.; Sa, R.-J.; Liu, T.-F.; Lu, J. Fluorescent Metal-Organic Framework (MOF) as a Highly Sensitive and Quickly Responsive Chemical Sensor for the Detection of Antibiotics in Simulated Wastewater. Inorg. Chem. 2018, 57, 1060-1065. [CrossRef] [PubMed] 
13. Bhattacharyya, S.; Chakraborty, A.; Jayaramulu, K.; Hazra, A.; Maji, T.K. A bimodal anionic MOF: Turn-off sensing of $\mathrm{Cu}-\mathrm{II}$ and specific sensitization of Eu-III. Chem. Commun. 2014, 50, 13567-13570. [CrossRef] [PubMed]

14. Guo, Y.; Feng, X.; Han, T.; Wang, S.; Lin, Z.; Dong, Y.; Wang, B. Tuning the luminescence of metal-organic frameworks for detection of energetic heterocyclic compounds. J. Am. Chem. Soc. 2014, 136, 15485-15488. [CrossRef] [PubMed]

15. Lei, Z.; Pei, X.L.; Jiang, Z.G.; Wang, Q.M. Cluster linker approach: preparation of a luminescent porous framework with $\mathrm{NbO}$ topology by linking silver ions with gold(I) clusters. Angew. Chem. Int. Ed. 2014, 53, 12771-12775. [CrossRef] [PubMed]

16. Tang, Y.; He, W.; Lu, Y.; Fielden, J.; Xiang, X.; Yan, D. Assembly of ruthenium-based complex into metal-organic framework with tunable area-selected luminescence and enhanced photon-to-electron conversion efficiency. J. Phys. Chem. C 2014, 118, 25365-25373. [CrossRef]

17. Guo, Z.; Song, X.; Lei, H.; Wang, H.; Su, S.; Xu, H.; Qian, G.; Zhang, H.; Chen, B. A ketone functionalized luminescent terbium metal-organic framework for sensing of small molecules. Chem. Commun. 2015, 51, 376-379. [CrossRef] [PubMed]

18. Li, Y.; Zhang, S.; Song, D. A luminescent metal-organic framework as a turn-on sensor for DMF vapor. Angew. Chem. Int. Ed. 2013, 52, 710-713. [CrossRef] [PubMed]

19. Allendorf, M.D.; Bauer, C.A.; Bhakta, R.K.; Houk, R.J. Luminescent metal-organic frameworks. Chem. Soc. Rev. 2009, 38, 1330-1352. [CrossRef] [PubMed]

20. Yan, L.; Yue, Q.; Jia, Q.-X.; Lemercier, G.; Gao, E.-Q. Lanthanide metal-organic frameworks based on octahedral secondary building units: rare net topology and luminescence. Cryst. Growth Des. 2009, 9, 2984-2987. [CrossRef]

21. Wei, Y.; Yu, Y.; Wu, K. Highly stable five-coordinated Mn(II) polymer [Mn(Hbidc) $]_{\mathrm{n}}$ (Hbidc=1H-Benzimidazole5,6-dicarboxylate): Crystal structure, antiferromagnetic property, and strong long-lived luminescence. Cryst. Growth Des. 2008, 8, 2087-2089. [CrossRef]

22. Bo, Q.B.; Wang, H.Y.; Wang, D.Q.; Znang, Z.W.; Miao, J.L.; Sun, G.X. Structure and photoluminescence tuning features of $\mathrm{Mn}\left(2^{+}\right)$- and $\operatorname{Ln}\left(3^{+}\right)$-activated $\mathrm{Zn}$-based heterometal-organic frameworks (MOFs) with a single 5-methylisophthalic acid ligand. Inorg. Chem. 2011, 50, 10163-10177. [CrossRef] [PubMed]

23. Wang, H.Y.; Wu, Y.; Leong, C.F.; D'Alessandro, D.M.; Zuo, J.L. Crystal structures, magnetic properties, and electrochemical properties of coordination polymers based on the tetra(4-pyridyl)-tetrathiafulvalene ligand. Inorg. Chem. 2015, 54, 10766-10775. [CrossRef] [PubMed]

24. Aijaz, A.; Sanudo, E.C.; Bharadwaj, P.K. Construction of coordination polymers with a bifurcating ligand: Synthesis, structure, photoluminescence, and magnetic studies. Cryst. Growth Des. 2011, 11, 1122-1134. [CrossRef]

25. Cai, S.L.; Zheng, S.R.; Wen, Z.Z.; Fan, J.; Wang, N.; Zhang, W.G. Two types of new three-dimensional $\mathrm{d}$-f heterometallic coordination polymers based on 2-(pyridin-3-yl)-1 H-imidazole-4,5-dicarboxylate and oxalate ligands: Syntheses, structures, luminescence, and magnetic properties. Cryst. Growth Des. 2012, 12, 4441-4449. [CrossRef]

26. Calahorro, A.J.; Salinas-Castillo, A.; Seco, J.M.; Zuñiga, J.; Colacio, E.; Rodríguez-Diéguez, A. Luminescence and magnetic properties of three metal-organic frameworks based on the 5-(1H-tetrazol-5-yl)isophthalic acid ligand. CrystEngComm 2013, 15, 7636-7639. [CrossRef]

27. Gao, W.; Li, P.; Liu, F.; Zhang, X.-M.; Liua, J.-P. Four metal-organic frameworks based on the 5-(1H-tetrazol-5-yl)isophthalic acid ligand: luminescence and magnetic properties. CrystEngComm 2016, 18, 1523-1531. [CrossRef]

28. Fang, Z.-L.; Yu, R.-M.; He, J.-G.; Zhang, Q.-S.; Zhao, Z.-G.; Lu, C.-Z. Structural, Luminescent, and Magnetic Properties of Three Novel Three-Dimensional Metal-Organic Frameworks Based on Hexadentate N,N'-bis(4-picolinoyl)hydrazine. Inorg. Chem. 2009, 48, 7691-7697. [CrossRef] [PubMed]

29. Zhang, H.-B.; Peng, Y.; Shan, X.-C.; Tian, C.-B.; Ping-Lin; Du, S.-W. Lanthanide metal organic frameworks based on octahedral secondary building units: Structural, luminescent, and magnetic properties. Inorg. Chem. Commun. 2011, 14, 1165-1169. [CrossRef]

30. Dey, C.; Kundu, T.; Biswal, B.P.; Mallick, A.; Banerjee, R. Crystalline metal-organic frameworks (MOFs): Synthesis, structure and function. Acta Crystallogr. 2014, B70, 3-10. [CrossRef] [PubMed] 
31. Coronado, E.; Mínguez Espallargas, G. Dynamic magnetic MOFs. Chem. Soc. Rev. 2013, 42, 1525-1539. [CrossRef] [PubMed]

32. Chen, P.; Batten, S.R.; Qi, Y.; Zheng, J.M. Two 3-D cluster-based frameworks: highly eight-connected molecular topology and magnetism. Cryst. Growth Des. 2009, 9, 2756-2761. [CrossRef]

33. Ouellette, W.; Prosvirin, A.V.; Whitenack, K.; Dunbar, K.R.; Zubieta, J. A Thermally and Hydrolytically Stable Microporous Framework Exhibiting Single-Chain Magnetism: Structure and Properties of $\left[\mathrm{Co}_{2}\left(\mathrm{H}_{0.67} \mathrm{bdt}\right)_{3}\right] \cdot 20 \mathrm{H}_{2} \mathrm{O}$. Angew. Chem. Int. Ed. 2009, 48, 2140-2143. [CrossRef] [PubMed]

34. Li, Y.-W.; Liu, S.-J.; Hu, T.-L.; Bua, X.-H. Doping cobalt into a [Zn7] cluster-based MOF to tune magnetic behaviour and induce fluorescence signal mutation. Dalton Trans. 2014, 43, 11470-11473. [CrossRef] [PubMed]

35. Bauer, C.A.; Timofeeva, T.V.; Settersten, T.B.; Patterson, B.D.; Liu, V.H.; Simmons, B.A.; Allendorf, M.D. Influence of Connectivity and Porosity on Ligand-Based Luminescence in Zinc Metal-Organic Frameworks. J. Am. Chem. Soc. 2007, 129, 7136-7144. [CrossRef] [PubMed]

36. Zou, R.; Abdel-Fattah, A.I.; Xu, H.; Burrell, A.K.; Larson, T.E.; McCleskey, T.M.; Wei, Q.; Janicke, M.T.; Hickmott, D.D.; Timofeeva, T.V.; Zhao, Y. Porous Metal-Organic Frameworks Containing Alkali-Bridged Two-Fold Interpenetration: Synthesis, Gas Adsorption, and Fluorescence Properties. Cryst. Growth Des. 2010, 10, 1301-1306. [CrossRef]

37. Zou, R.; Zhong, R.; Han, S.; Xu, H.; Burrell, A.K.; Henson, N.; Cape, J.L.; Hickmott, D.D.; Timofeeva, T.V.; Larson, T.E.; et al. A Porous Metal-Organic Replica of $\alpha-\mathrm{PbO}_{2}$ for Capture of Nerve Agent Surrogate. J. Am. Chem. Soc. 2010, 132, 17996-17999. [CrossRef] [PubMed]

38. Wei, Q.; Yang, D.; Larson, T.E.; Kinnibrugh, T.L.; Zou, R.; Henson, N.J.; Timofeeva, T.; Xu, H.; Zhao, Y.; Mattes, B.R. Kinetic hysteresis in gas adsorption behavior for a rigid MOF arising from zig-zag channel structures. J. Mater. Chem. 2012, 22, 10166-10171. [CrossRef]

39. Ordonez, C.; Kinnibrugh, T.L.; Xu, H.; Lindline, J.; Timofeeva, T.; Wei, Q. Synthesis of Framework Isomer MOFs Containing Zinc and 4-Tetrazolyl Benzenecarboxylic Acid via a Structure Directing Solvothermal Approach. Crystals 2015, 5, 193-205. [CrossRef]

40. Ordonez, C.; Fonari, M.S.; Wei, Q.; Timofeeva, T.V. Crystal structure of poly[bis(ammonium) [bis( $\mu 4$-benzene-1,3,5-tricarboxylato)dizincate] 1-methylpyrrolidin-2-one disolvate]. Acta Crystallogr. 2016, E72, 764-767. [CrossRef] [PubMed]

41. Ordonez, C.; Fonari, M.; Lindline, J.; Wei, Q.; Timofeeva, T.V. How Structure-directing cations tune the fluorescence of metal-organic frameworks. Cryst. Growth Des. 2014, 14, 5452-5465. [CrossRef]

42. Xie, L.H.; Liu, S.X.; Gao, B.; Zhang, C.D.; Sun, C.Y.; Li, D.H.; Su, Z.M. A three-dimensional porous metal-organic framework with the rutile topology constructed from triangular and distorted octahedral building blocks. Chem. Commun. 2005, 2402-2404. [CrossRef] [PubMed]

43. Xie, L.H.; Lin, J.B.; Liu, X.M.; Xue, W.; Zhang, W.X.; Liu, S.X.; Zhang, J.P.; Chen, X.M. Organic ammonium ion-occluded flexible coordination polymers: Thermal activation, structure transformation and proton transfer. Sci. China. Chem. 2010, 53, 2144-2151. [CrossRef]

44. Zhao, X.J.; Tao, J. A three-dimensional zinc trimesate framework: $\left[\left(\mathrm{CH}_{3}\right)_{2} \mathrm{NH}_{2}\right]\left[\mathrm{Zn}_{(}\left(\mathrm{C}_{9} \mathrm{H}_{3} \mathrm{O}_{6}\right)\right] \cdot\left(\mathrm{C}_{3} \mathrm{H}_{7} \mathrm{NO}\right)$. Appl. Organomet. Chem. 2005, 19, 694-695. [CrossRef]

45. Verwey, E.J.W. Electronic Conduction of Magnetite $\left(\mathrm{Fe}_{3} \mathrm{O}_{4}\right)$ and its Transition Point at Low Temperatures. Nature 1939, 144, 327-328. [CrossRef]

46. Chen, W.; Wang, J.Y.; Chen, C.; Yue, Q.; Yuan, H.-M.; Chen, J.-S.; Wang, S.-N. Photoluminescent metal-organic polymer constructed from trimetallic clusters and mixed carboxylates. Inorg. Chem. 2003, 42, 944-946. [CrossRef] [PubMed]

47. Fang, Q.; Zhu, G.; Xue, M.; Sun, J.; Sun, F.; Qiu, S. Structure, luminescence, and adsorption properties of two chiral microporous metal-organic frameworks. Inorg. Chem. 2006, 45, 3582-3587. [CrossRef] [PubMed]

48. Dai, J.-C.; Wu, X.-T.; Fu, Z.-Y.; Cui, C.-P.; Hu, S.-M.; Du, W.-X.; Wu, L.-M.; Zhang, H.-H.; Sun, R.-Q. Synthesis, structure, and fluorescence of the novel cadmium(II)-trimesate coordination polymers with different coordination architectures. Inorg. Chem. 2002, 41, 1391-1396. [CrossRef] [PubMed]

49. Dunlop, D.; Özdemir, Ö. Rock Magnetism: Fundamentals and Frontiers; Cambridge University Press: New York, NY, USA, 1997; p. 573, ISBN 0521325145.

50. Moskowitz, B.M.; Jackson, M.; Kissel, C. Low-temperature magnetic behavior of titanomagnetites. Earth Planet. Sci. Lett. 1998, 157, 141-149. [CrossRef] 
51. Bowles, J.; Jackson, M.; Chen, A.; Solheid, P. Interpretation of Low-Temperature Data Part 1: Superparamagnetism and Paramagnetism. IRM Q. 2009, 19, 7-11.

52. Moskowitz, B.M.; Frankel, R.B.; Bazylinski, D.A. Rock magnetic criteria for the detection of biogenic magnetite. Earth Planet. Sci. Lett. 1993, 120, 283-300. [CrossRef]

53. Smirnov, A.V. Grain size dependence of low-temperature remanent magnetization in natural and synthetic magnetite: Experimental study. Earth Planets Space 2009, 61, 119-124. [CrossRef]

54. Verwey, E.J.; Haayman, P.W.; Romeijn, F.C. Physical properties and cation arrangements of oxides with spinel structure II. Electronic conductivity. J. Chem. Phys. 1947, 15, 181-187. [CrossRef]

55. Xu, X.; Xu, C.; Lin, Y.; Li, J.; Hu, J. Comparison on Photoluminescence and Magnetism between Two Kinds of Undoped ZnO Nanorods. J. Phys. Chem. C 2013, 117, 24549-24553. [CrossRef]

56. Ganguli, N.; Dasgupta, I.; Sanyal, B. Electronic structure and magnetism of transition metal doped $\mathrm{Zn}_{12} \mathrm{O}_{12}$ clusters: Role of defects. J. Appl. Phys. 2010, 108, 123911. [CrossRef]

(C) 2018 by the authors. Licensee MDPI, Basel, Switzerland. This article is an open access article distributed under the terms and conditions of the Creative Commons Attribution (CC BY) license (http://creativecommons.org/licenses/by/4.0/). 